Portland State University

PDXScholar

2-10-1994

\title{
Solubility Studies of Iron(III) Oxides and Hydroxides
}

Victor L. Menting

Portland State University

Follow this and additional works at: https://pdxscholar.library.pdx.edu/open_access_etds

Part of the Chemistry Commons

Let us know how access to this document benefits you.

\section{Recommended Citation}

Menting, Victor L., "Solubility Studies of Iron(III) Oxides and Hydroxides" (1994). Dissertations and Theses. Paper 4853.

https://doi.org/10.15760/etd.6729

This Thesis is brought to you for free and open access. It has been accepted for inclusion in Dissertations and Theses by an authorized administrator of PDXScholar. Please contact us if we can make this document more accessible: pdxscholar@pdx.edu. 


\section{THESIS APPROVAL}

The abstract and thesis of Victor $\mathrm{L}$. Menting for the Master of Science in Chemistry was presented February 10, 1994, and accepted by the thesis committee and the department.

COMMITTEE APPROVALS:

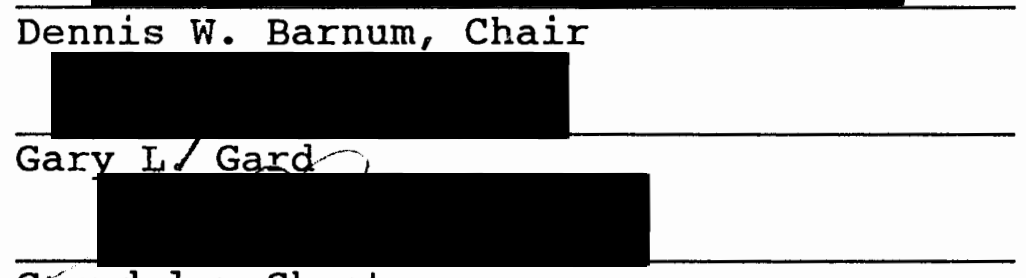

Gwendolyn Shusterman

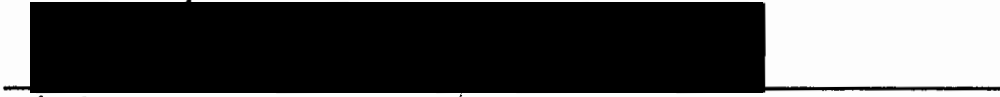

Richard R. Petersen

DEPARTMENTAL APPROVAL:

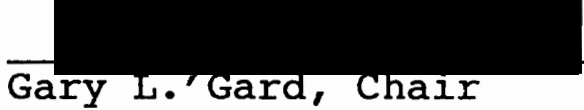

Department of Chemistry

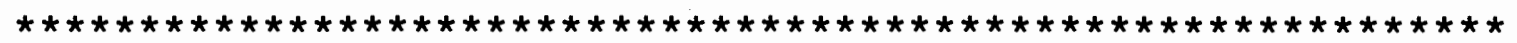

ACCEPTED FOR PORTLAND STATE UNIVERSITY BY THE LIBRARY

by.

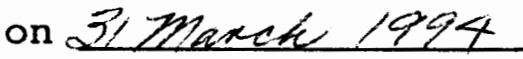




\section{ABSTRACT}

An abstract of the thesis of Victor L. Menting for the Master of Science in Chemistry presented February 10, 1994.

Title: Solubility Studies of Iron(III) Oxides And Hydroxides .

The hydrolysis of iron(III) ions in aqueous solution forms a series of soluble hydroxide complexes with associated equilibrium constants. The solubility of iron(III) is controlled by the various soluble hydroxide complexes, and can, in theory, be calculated from the $\mathrm{pH}$ and equilibrium constants. Experimental verification of the calculated solubility has proven difficult due to the lack of sensitive analytical techniques and the presence of colloidal ferric hydroxide interferences.

Recently, electrochemical methods for the determination of low levels of iron(III) have been developed using adsorptive cathodic stripping voltammetry which relies on the interfacial accumulation of the chelate of iron with Solochrome Violet RS on a hanging mercury drop electrode.

The purpose of this investigation was to experimentally verify the calculated solubility of iron(III) in the pH 4-12 region using adsorptive cathodic stripping voltammetry • The ubiquitous nature of iron requires background 
levels of iron be reduced below the experimental concentrations to be determined. Attempts to lower the background levels of iron were ineffective as concentrations below about $10^{-8} \mathrm{M}$ iron could not be attained.

Verification of the calculated solubility of iron(III) was unsuccessful as background concentrations of iron(III) and the presence of colloidal ferric hydroxide hindered the experimental results. The dissolution of the ferric hydroxide colloids coupled with the background levels of iron resulted in the determination of experimental concentrations which exceeded theoretical values by two to four orders of magnitude. 


\section{SOLUBILITY STUDIES OF IRON(III) \\ OXIDES AND HYDROXIDES}

by

VICTOR L. MENTING

A thesis submitted in partial fulfillment of the requirements for the degree of

\section{MASTER OF SCIENCE \\ in \\ CHEMISTRY}

Portland State University 1994 


\section{DEDICATION}

This work is dedicated to the two people I admire and respect most, my parents, James R. and Judith A. Menting. Their love and support has been a constant source of inspiration. 


\section{ACKNOWLEDGEMENTS}

The author would like to extend his deepest gratitude and sincerest appreciation to Dr. Dennis Barnum for sharing his wealth of knowledge. Dr. Barnum's insights greatly aided the author in the completion of this investigation. 
TABLE OF CONTENTS

PAGE

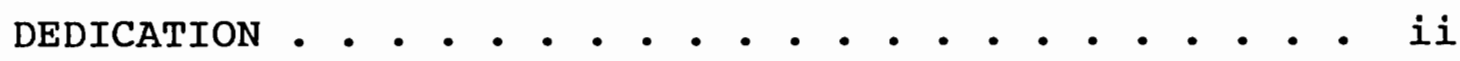

ACKNOWLEDGEMENTS • • • • • • . • • • • • • • . . . iii

LIST OF TABLES • • • • • • • • • • • • • • • • • • v

LIST OF FIGURES • • • • • • • • • • • • • • • • • • vi v vi
\end{abstract}

CHAPTER

I INTRODUCTION • • • • • • • • • • • • • 1

Theory . . . . . . . . . . . 1

II EXPERIMENTAL . . . . . . . . . . . . 10

Apparatus . . . . . . . . . . 10

Possible Sources of Iron Contamination . 19

III RESULTS . . . . . . . . . . . . 33

Differential Pulse Polarography . . . 33

Fast Scan D.C. Polarography . . . . 42

IV DISCUSSION . . . . . . . . . . . . 46

Conclusions . . . . . . . . . . 46

Future Work . . . . . . . . . 53

V REFERENCES • . . . . . . . . . . . . 54

Literature Cited . . . . . . . . 54

Selected Bibliography . . . . . . 56 
LIST OF TABLES

TABLE

PAGE

I Equilibrium Reactions And Equilibrium

Constants For The Iron(III) Hydroxy

Complexes From Baes And Mesmer [1976] • 2

II Literature Equilibrium Constants . . . . . 4

III Solubility Product Constants of The

Different Crystalline Forms of Ferric

Hydroxide $\mathrm{K}_{\mathrm{sp}}=\left[\mathrm{Fe}^{3+}\right] *\left[\mathrm{OH}^{-}\right]^{3}$ From

Lindsay [1985] • • • • • • • . 8

IV Preparation of Buffers With Actual pH's,

Ionic Strengths, And Buffer System . . 14

V Concentration of Citrate (ng/mL) Added And

The Resulting Peak Current Increases . 20

VI Change In The Calculated Iron Concentration

For Buffers with And without Filtration 22

VII Increases In Current with Time At Various

Conditions Involving Solution stirring

And Nitrogen Purging . . . . . . . 31

VIII Concentration of Total Dissolved Iron(III)

Calculated From Aqueous Ferric

Perchlorate, Colloidal Ferric Hydroxide,

And Goethite At Various pH's . . . . 38 
LIST OF FIGURES

FIGURE

PAGE

1. Calculated Solubility of $\mathrm{Fe}(\mathrm{OH})_{3}(\mathrm{~s})$ Using

The Equilibrium Constants Presented By Stumm and Morgan [1981] . . . . . . . 3

2. Comparison of The Calculated Solubility of

$\mathrm{Fe}(\mathrm{OH})_{3}(\mathrm{~s})$ With Experimental Solubility

Measurements From The Literature . . 5

3. Structure of Solochrome violet RS . . . . 17

4. Concentration Versus Time Showing The Dissolution

of Colloidal Ferric Hydroxide . . . . 24

5. Concentration Versus Total Iron Added As Colloidal

Ferric Hydroxide . . . . . . . 26

6. Differential Pulse Voltammogram of Solution

Containing Supporting electrolyte/SVRS And

Iron, Spiked With Al(III) . . . . . 28

7. Approximate Concentration of Iron As A Function of

Time To Determine The Extent of Iron

Contamination Resulting From Iron Diffusion

Out of The Electrode Frit . . . . . 29 
8. Voltammograms Obtained In The Differential

Pulse Mode For SVRS Containing Solutions

In The Absence And Presence of Added Iron . . . . . . . . . . .

9. Voltammograms of Current Versus Added Iron

In The Differential Pulse Mode . . . 35

10. Analysis of Background Iron By Standard Addition

For Differential Pulse Polarography . . 36

11. Comparison of Calculated Solubility with

Experimental Concentrations of Iron In

Solutions Equilibrated With Ferric

Perchlorate . . . . . . . . 39

12. Comparison of Calculated Solubility with

Experimental Concentrations of Iron In

Solutions Equilibrated with Colloidal Ferric

Hydroxide . . . . . . . . . 40

13. Comparison of Calculated Solubility With

Experimental Concentrations of Iron In

Solutions Equilibrated with Goethite • 41

14. Voltammogram of Fast Scan D.C. Polarography 43

15. Analysis of Background Iron By Standard Addition

For Fast Scan D.C. Polarography . . . 45

16. Comparison of The Solubility of $\mathrm{Fe}(\mathrm{OH})_{2.35} \mathrm{x}_{0.65}$

Calculated Using The Solubility Product

Proposed By Fox [1988] . . . . . 47 
17. Comparison of The Solubility of $\mathrm{Fe}(\mathrm{OH})_{2.35} \mathrm{x}_{0.65}$ Calculated Using The Solubility Product Proposed By Fox [1988], with The Experimentally Measured Solubility Found In This study . . . . . . . . . 48

18. Graphical Representation of $\mathrm{U}\left\{\mathrm{M}(\mathrm{OH})_{\mathrm{y}}\right\}$ Versus y For Literature Values of The Equilibrium Constants of The Iron Hydroxy Complexes . . . . . . . . . . 51 


\section{CHAPTER I}

\section{INTRODUCTION}

\section{THEORY}

Iron(III) ions in aqueous solution are surrounded by a primary hydration sphere of six water molecules, $\mathrm{Fe}\left(\mathrm{H}_{2} \mathrm{O}\right)_{6}{ }^{3+}$. As the $\mathrm{pH}$ increases, $\mathrm{H}^{+}$ions are removed from the hydration sphere to form a series of soluble hydroxide complexes according to the reaction (water molecules are omitted for brevity):

$$
\mathrm{xFe}+\mathrm{y} \mathrm{H}_{2} \mathrm{O} \Leftrightarrow \mathrm{Fe}_{\mathrm{x}}(\mathrm{OH})_{\mathrm{y}}^{(3 \mathrm{x}-\mathrm{y})+}+\mathrm{y} \mathrm{\textrm {H } ^ { + }}
$$

The complexes formed are the mononuclear $\mathrm{Fe}(\mathrm{OH})^{2+}, \mathrm{Fe}(\mathrm{OH})_{2}^{+}$, $\mathrm{Fe}(\mathrm{OH})_{3}^{\circ}$, and $\mathrm{Fe}(\mathrm{OH})_{4}^{-} ;$and the polynuclear complexes $\mathrm{Fe}_{2}(\mathrm{OH})_{2}{ }^{4+}$ and $\mathrm{Fe}_{3}(\mathrm{OH})_{4}{ }^{5+}$. (The superscript "O" in $\mathrm{Fe}(\mathrm{OH})_{3}{ }^{\circ}$ will be used to distinguish the neutral water soluble complex from the $\mathrm{Fe}(\mathrm{OH})_{3}$ precipitate.) For simplicity, the general form, $\mathrm{K}_{\mathrm{xy}}$, will be used for the equilibrium constant of the complex, $\mathrm{Fe}_{\mathbf{x}}(\mathrm{OH})_{y}^{3 \mathrm{x}-\mathrm{y}}$. Equilibrium constants are given in Table I.

The following equation can be written to describe the solubility of iron(III) in aqueous solution:

$$
\begin{gathered}
{\left[\mathrm{Fe}^{3+}\right]_{\mathrm{T}}=\left[\mathrm{Fe}^{3+}\right]+\left[\mathrm{Fe}(\mathrm{OH})^{2+}\right]+\left[\mathrm{Fe}(\mathrm{OH})_{2}^{+}\right]+\left[\mathrm{Fe}(\mathrm{OH})_{3}{ }^{0}\right]+} \\
{\left[\mathrm{Fe}(\mathrm{OH})_{4}{ }^{-}\right]+2\left[\mathrm{Fe}_{2}(\mathrm{OH})_{2}{ }^{4+}\right]+3\left[\mathrm{Fe}_{3}(\mathrm{OH})_{4}{ }^{5+}\right]}
\end{gathered}
$$

where $\left[\mathrm{Fe}^{3+}\right]_{\mathrm{T}}$ is the total iron concentration, i.e. the 
solubility.

TABLE I

EQUILIBRIUM REACTIONS AND EQUILIBRIUM CONSTANTS

FOR THE IRON(III) HYDROXY COMPLEXES

FROM BAES AND MESMER [1976]

$\begin{array}{ll}\text { Equilibrium Reaction } & \log \mathrm{K} \\ \mathrm{Fe}_{\mathrm{je}}{ }^{3+}+\mathrm{H}_{2} \mathrm{O} \Leftrightarrow=\mathrm{FeOH} & -3.05 \\ \mathrm{Fe}^{3+}+2 \mathrm{H}_{2} \mathrm{O} \Leftrightarrow=\mathrm{Fe}(\mathrm{OH})^{+}{ }^{+}+2 \mathrm{H}^{+} & -6.31 \\ \mathrm{Fe}^{3+}+3 \mathrm{H}_{2} \mathrm{O} \Leftrightarrow>\mathrm{Fe}(\mathrm{OH})^{3}+3 \mathrm{H}^{+} & <-12 \\ \mathrm{Fe}^{3+}+4 \mathrm{H}_{2} \mathrm{O} \Leftrightarrow>\mathrm{Fe}(\mathrm{OH})_{4}+4 \mathrm{H}^{+} & -21.6 \\ 2 \mathrm{Fe}^{3+}+2 \mathrm{H}_{2} \mathrm{O} \Leftrightarrow=\mathrm{Fe}_{2}(\mathrm{OH})^{4+}+2 \mathrm{H}^{+} & -2.96 \\ 3 \mathrm{Fe}^{3+}+4 \mathrm{H}_{2} \mathrm{O} \Leftrightarrow=\mathrm{Fe}_{3}(\mathrm{OH})_{4}+4 \mathrm{H}^{+} & -5.77\end{array}$

Substitution of the equilibrium expressions for the complexes into Equation 2 yields:

$$
\begin{gathered}
{\left[\mathrm{Fe}^{3+}\right]_{\mathrm{T}}=\mathrm{K}_{\mathrm{sp}}\left(\mathrm{K}_{11}\left[\mathrm{H}^{+}\right]^{-1}+\mathrm{K}_{12}\left[\mathrm{H}^{+}\right]^{-2}+\mathrm{K}_{13}\left[\mathrm{H}^{+}\right]^{-3}+\mathrm{K}_{14}\left[\mathrm{H}^{+}\right]^{-4}+\right.} \\
2 \mathrm{~K}_{22}{ }^{2}\left[\mathrm{H}^{+}\right]^{-2}+3\left(\mathrm{~K}_{34}\left[\mathrm{H}^{+}\right]^{-4}\right)
\end{gathered}
$$

where $K_{x y}$ is the equilibrium constant for the $\mathrm{Fe}_{x}(\mathrm{OH})_{y}^{3 x-y}$ complex. From Equation 3 it can be seen that the solubility depends on the $\mathrm{pH}$ and can, in principle, be calculated from known equilibrium constants. The concentration of soluble iron in a solution saturated with $\mathrm{Fe}(\mathrm{OH})_{3}(\mathrm{~s})$ is graphically represented in Figure 1 as a function of $\mathrm{pH}$. It can be seen that the solubility of $\mathrm{Fe}(\mathrm{OH})_{3}(\mathrm{~s})$ is controlled by the various soluble hydroxide complexes. [The polynuclear complexes -- $\mathrm{Fe}_{2}(\mathrm{OH})_{2}^{+4}$ and $\mathrm{Fe}_{3}(\mathrm{OH})_{4}^{+5}--$ will be ignored, as such complexes are important only in fairly concentrated solutions (above approximately 0.01M).]

Experimental verification of the calculated solubility

${ }^{1}$ Determined at $25^{\circ} \mathrm{C}$ with $\mathrm{I}=1.5$ 


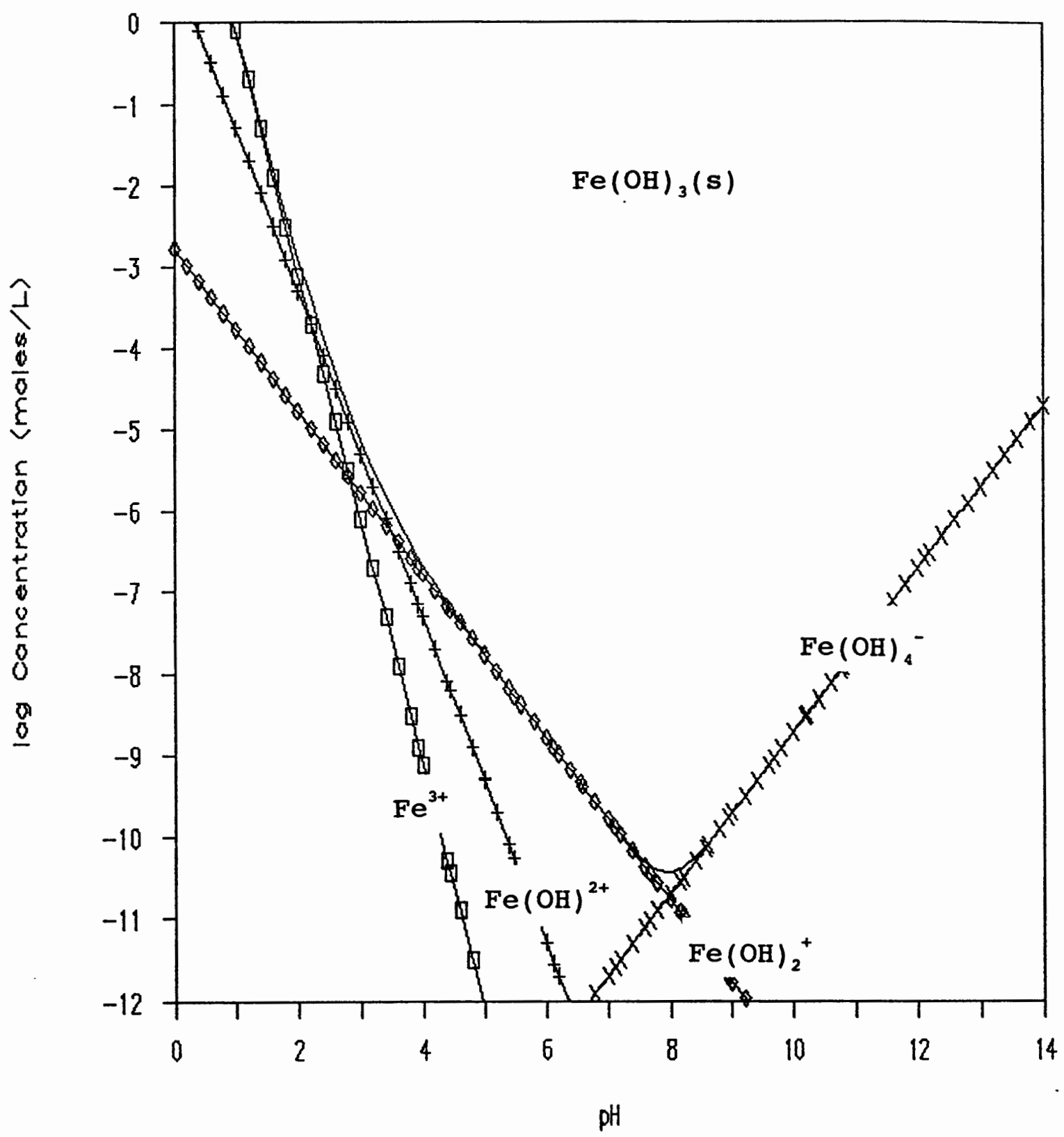

Figure 1. Calculated solubility of $\mathrm{Fe}(\mathrm{OH})_{3}(\mathrm{~s})$ using the equilibrium constants presented by Stumm and Morgan [1981]. Note that stumm and Morgan omitted $\mathrm{Fe}(\mathrm{OH})_{3}^{\circ}$ from their calculations. $(-)=$ $\left[\mathrm{Fe}^{3+}\right]_{\mathrm{T}}\left(\log \mathrm{K}_{\mathrm{sp}}=-39.1, \log \mathrm{K}_{11}=-2.19, \log \mathrm{K}_{12}\right.$ $=-5.67$, and $\left.\log \mathrm{K}_{14}=-21.6\right)$ 
curve as seen in Figure 1, has proven to be difficult. Figure 2 compares the calculated solubility of $\mathrm{Fe}(\mathrm{OH})_{3}(\mathrm{~s})$ with experimental measurements taken from the literature. clearly, agreement is poor, although it might be made to appear better depending on the values selected for $\mathrm{K}_{13}$ and $\mathrm{K}_{\mathrm{sp}}$. Furthermore data at high $\mathrm{pH}$ values are lacking. In the $\mathrm{pH}$ 6-10 range the solubility might be controlled by the soluble $\mathrm{Fe}(\mathrm{OH})_{3}^{\circ}$, however the value of $\mathrm{K}_{13}$ is not well established. So little is known and understood about this equilibrium constant that some authors [Stumm and Morgan, 1981; and Martell and Smith, 1982 ] exclude $\mathrm{K}_{13}$ from their solubility calculations as shown in Figure 1. Table II shows different values of $\mathrm{K}_{13}$ taken from the literature. An initial objective of this research was to obtain a more reliable value.

TABLE II

LITERATURE EQUILIBRIUM CONSTANTS

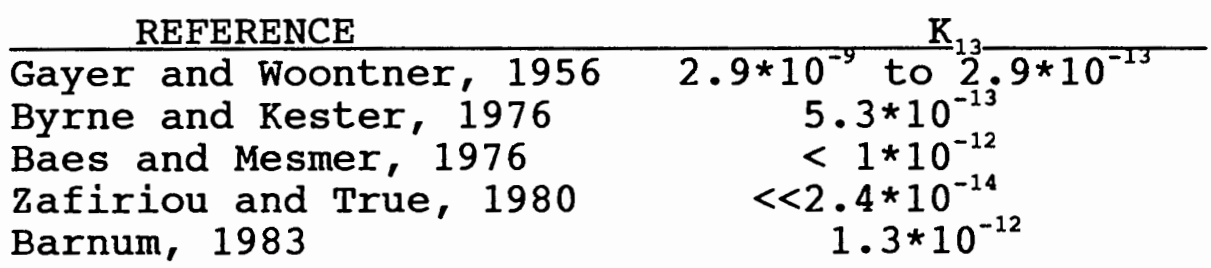

One problem in the experimental verification of $\mathrm{K}_{13}$ is the lack of sensitive analytical techniques which determine sub-nanomolar concentrations of iron. Colloidal ferric hydroxide particles are also a problem as they can pass through all but the finest pore size filters and dialysis 


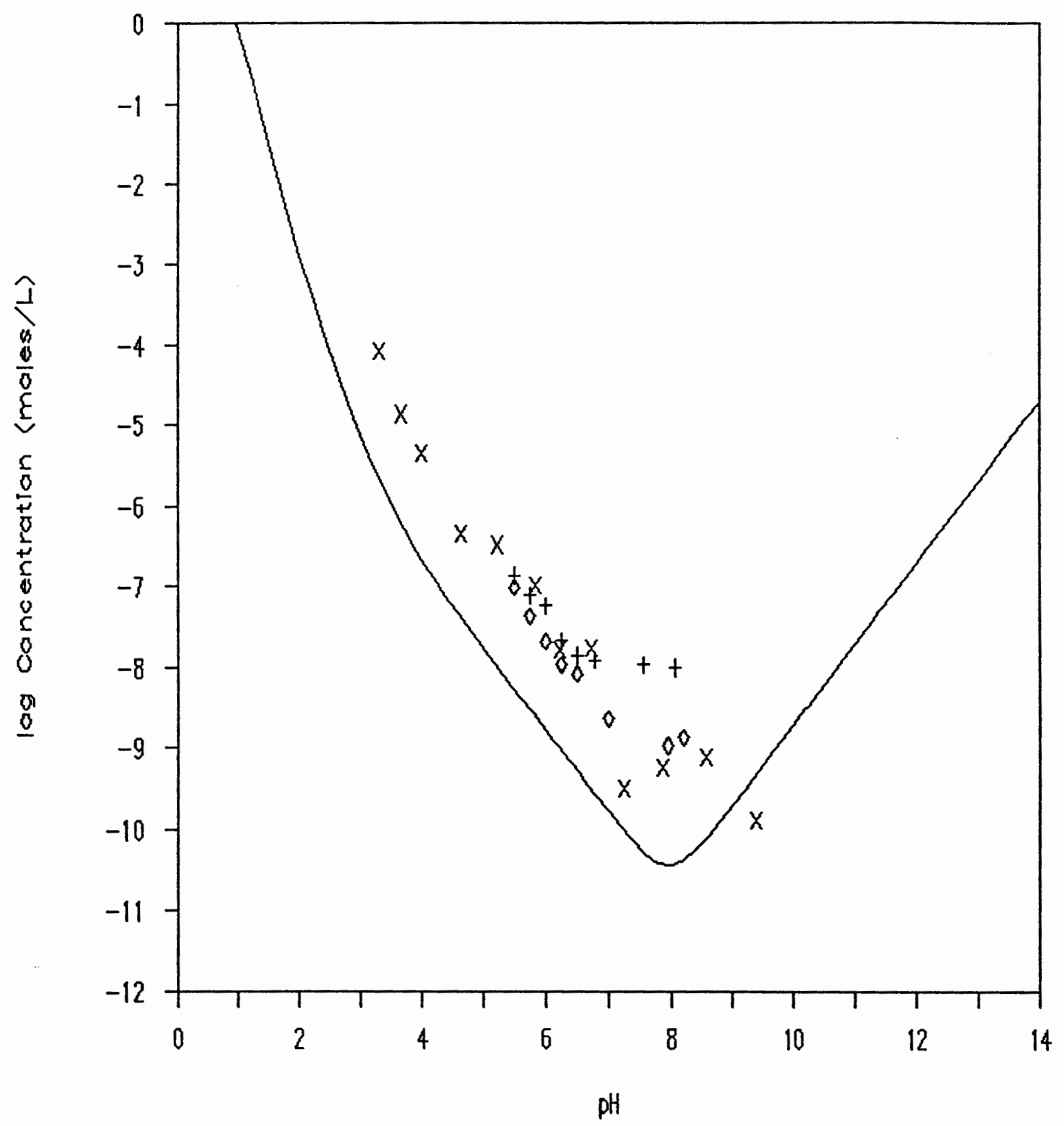

Figure 2. Comparison of the calculated solubility $(-)$ of $\mathrm{Fe}(\mathrm{OH})_{3}(\mathrm{~s})$ with experimental solubility measurements from the literature. (X)Kuma, et al. [1992], ( $\diamond)$ Kuma, et al. [1993], and $(+)$ Byrne and Kester [1976]. 
tubing, interfering with the determination of iron.

Another problem is the nature of the ferric hydroxide solid phase. Different solid forms of ferric hydroxide are known: fresh ("active") and aged ("inactive") amorphous ferric hydroxide $\left(\mathrm{Fe}(\mathrm{OH})_{3} \cdot \mathrm{nH}_{2} \mathrm{O}\right)$, a hypothesized amorphous non-stoichiometric $\mathrm{Fe}(\mathrm{OH})_{2.35} \mathrm{X}_{0.65}$, goethite $(\alpha-\mathrm{FeOOH})$, akaganeite $(\beta-\mathrm{FeOOH})$, lepidocrocite $(\gamma-\mathrm{FeOOH})$, feroxyhyte $(\delta-\mathrm{FeOOH})$, haematite $\left(\alpha-\mathrm{Fe}_{2} \mathrm{O}_{3}\right)$, and maghemite $\left(\gamma-\mathrm{Fe}_{2} \mathrm{O}_{3}\right)$.

Amorphous Ferric Hydroxide, $\mathrm{Fe}(\mathrm{OH})_{3} \cdot \mathrm{nH}_{2} \mathrm{O}$

Amorphous ferric hydroxide, also known as hydrous ferric oxide, changes slowly with age. The "active" form is freshly precipitated, while the "inactive" form is aged. Both crystalline forms are produced by the addition of base to aqueous iron(III). Still further aging, over a period of months or years, results in a slow transformation to goethite and haematite; in some cases akaganeite and lepidocrocite forms on aging [Kolthoff, et al., 1969].

Non-Stoichiometric $\mathrm{Fe}(\mathrm{OH})_{2.35}(\mathrm{X})_{0.65}$

Fox [1988] suggested that amorphous ferric hydroxide is non-stoichiometric, as $\mathrm{Fe}(\mathrm{OH})_{2.35}(\mathrm{X})_{0.65}$.

Goethite, $\alpha-\mathrm{FeO}(\mathrm{OH})$

Goethite, a crystalline form of iron(III) hydroxide, is formed by slow hydrolysis of iron(III) salts -- although $\mathrm{FeCl}_{3}$ results in akaganeite -- or by aging of ferrihydrite 
$\left(\mathrm{Fe}_{5} \mathrm{O}_{3}(\mathrm{OH})_{9}\right)$ [Schwertmann and Taylor, 1977]. Goethite can

also be formed by the conversion of lepidocrocite in alkali hydroxide or ferrous sulfate solutions [Schwertmann and Taylor, 1972].

Akaganeite, $\mathrm{B}-\mathrm{FeO}(\mathrm{OH})$

Crystalline akaganeite formation occurs by the hydrolysis of iron(III) in solutions containing chloride or fluoride ions [Sherman, et al., 1982].

Lepidocrocite, $\gamma$-FeOOH

Lepidocrocite, a crystalline solid, is formed by oxidation of precipitated $\mathrm{Fe}(\mathrm{OH})_{2}$ (amakinite) at lower $\mathrm{pH}$ and temperature and in the absence of iron(III) ions [Kabata-Pendias and Pendias, 1984].

Feroxyhyte, $\delta$-FeOOH

Feroxyhyte forms a crystalline solid by violent oxidation of $\mathrm{Fe}(\mathrm{OH})_{2}$ (amakinite) in very basic solutions [Schwertmann and Taylor, 1977].

Haematite, $\alpha-\mathrm{Fe}_{2} \underline{\mathrm{O}}_{3}$

Crystalline haematite formation results from the transformation of ferrihydrite or by dehydration of goethite at elevated temperatures [Sherman, et al., 1982].

Maghemite, $\gamma-\mathrm{Fe}_{2} \underline{\mathrm{O}}_{3}$

Crystalline maghemite typically is formed by the 
oxidation of magnetite $\left(\mathrm{Fe}_{3} \mathrm{O}_{4}\right)$, but thermal dehydration of lepidocrocite can occur [Sherman, et al., 1982].

The various solid forms of the iron(III) minerals have different solubility products as seen in Table III. The literature values for the solubility product of ferric hydroxide vary from $10^{-35.5}$ to $10^{-44}$ [Stumm and Lee, 1960]. Most of the literature values make no mention as to the solid form of iron(III) or the age of the precipitate used. Since the solid forms, and therefore the solubilities, form an intricate network of interconversions, it is important to select the appropriate solubility product for calculations.

\section{TABLE III}

\section{SOLUBILITY PRODUCT CONSTANTS OF THE DIFFERENT CRYSTALLINE FORMS OF FERRIC HYDROXIDE $\mathrm{K}_{\mathrm{Bp}}=\left[\mathrm{Fe}^{3+}\right] *[\mathrm{OH}]^{3}$ FROM LINDSAY [1985].}

\begin{tabular}{lc} 
Crystal Form & $\mathrm{K}_{\mathrm{sp}}$ \\
\hline Amorphous, $\mathrm{Fe}(\mathrm{OH})_{3} \cdot \mathrm{nH}_{2} \mathrm{O}$ & $3.5 * 10^{-39}$ \\
Non-Stoichiometric, $\mathrm{Fe}(\mathrm{OH})_{2.35} \mathrm{X}_{0.65}^{2}$ & $2.0 * 10^{-32}$ \\
Goethite, $\alpha-\mathrm{FeO}(\mathrm{OH})$ & $9.6 * 10^{-43}$ \\
Lepidocrocite, $\gamma-\mathrm{FeO}(\mathrm{OH})$ & $2.5 * 10^{-41}$ \\
Haematite, $\alpha-\mathrm{Fe}_{2} \mathrm{O}_{3}$ & $1.2 * 10^{-42}$ \\
Maghemite, $\gamma-\mathrm{Fe}_{2} \mathrm{O}_{3}$ & $3.9 * 10^{-41}$
\end{tabular}

Recently, electrochemical methods for the determination of low concentrations of iron(III) in aqueous solutions have been developed. Levels of iron as low as $10^{-9}-10^{-10} \mathrm{M}$ can be determined using adsorptive cathodic stripping voltammetry

${ }^{2}$ From Fox [1988]; with $\mathrm{K}_{\mathrm{Bp}}=\left[\mathrm{Fe}^{3+}\right]\left[\mathrm{OH}^{-}\right]^{2.35}$, and $\mathrm{X}$ is an anion belonging to the solvent and can be emitted from the expression as its concentration is constant. 
(CSV). The procedure relies on the interfacial accumulation of the chelate of iron with Solochrome violet RS (SVRS) on a hanging mercury drop electrode. Iron(III) forms a complex with SVRS at $\mathrm{pH}$ values between 4 and 5, while iron(II) does not [Latimer, 1968]. This method offers several advantages such as: detection of iron(III) in the presence of other metal ions, including iron(II), and a detection limit of $0.04 \mu \mathrm{g} / \mathrm{L}\left(7 * 10^{-10} \mathrm{M}\right)$ iron(III) (calculated from 3 times the noise) [Wang and Mahmoud, 1987].

The purpose of this investigation was to experimentally verify the calculated solubility of iron(III) in the $\mathrm{pH} 4-12$ region using adsorptive CSV. 
CHAPTER II

EXPERIMENTAL

APPARATUS

\section{Polarograph}

The polarographic equipment used was a PAR 264A Voltammetric Analyzer connected to a PAR303A Static Mercury Drop Electrode. Purge time, deposition time, equilibration time, and scan time were controlled by the potentiostat. The drop size used was "medium", which gave an approximate surface area of $0.015 \mathrm{~cm}^{2}$. Solutions were stirred using a teflon coated stirring bar. Borosilicate glass, plastic, or siliconized glass voltammetric cells (EG\&G PARC) were used. The nitrogen line used for purging solutions was equipped with an activated carbon column, a zeolite column, and a $0.20 \mu \mathrm{m}$ filter.

The mercury was examined by atomic emission spectrographic analysis and proved to have no detectible impurities.

\section{Clean Box}

To provide a dust free working environment, experiments were carried out in a dry box fitted with a fan to circulate air through an electrostatically charged, high performance 
Hammock clean air filter (Filtrete by $3 \mathrm{M}$ ). The gloves were removed and the holes covered with two layers of the clean air filter material.

\section{Cleaning Protocol}

All glassware was cleaned by soaking in hydrochloric acid via the following protocol. The glassware was washed in warm tap water with standard laboratory soap (Labtone or Sparkleen), rinsed five times with tap water, five times with deionized water, and placed in a hydrochloric acid bath. Smaller glassware was soaked in $6 \mathrm{M} \mathrm{HCl}$ for a minimum of four hours; while the larger glassware was soaked in $1.5 \mathrm{M}$ HCl for a minimum of 12 hours. After the acid bath, glassware was rinsed five times with deionized water and placed inverted in the clean box to air dry.

\section{Water}

"Nanopure" Water. Deionized water was used to prepare all solutions and wash the equipment and glassware. Tap water was distilled and passed through a Barnstead NANOpure II Water System, consisting of an organic removal cartridge, two ion exchange cartridges, a submicron filter, and a bacterial removal filter.

Quartz Distilled Water. The preparation of quartz distilled water (Q-water) was accomplished by first distilling deionized water over alkaline $\mathrm{KMnO}_{4}$ to oxidize any organics, then a second distillation, and finally a sub- 
boiling point distillation. The entire apparatus was constructed of quartz.

Sodium Hydroxide And Hydrochloric Acid

A $1.075 \mathrm{M}$ solution of sodium hydroxide was prepared by diluting 19M (50\%) sodium hydroxide (J.T. Baker Chemical Co.) in nanopure water. The solution was standardized by titration with primary standard potassium acid phthalate to the phenolphthalein end point and stored in a plastic container equipped with a soda lime tube to prevent the absorption of carbon dioxide.

A $1.124 \mathrm{M}$ solution of hydrochloric acid was prepared by diluting 12M (35\%) hydrochloric acid (J.T. Baker Chemical Co.) with nanopure water. The solution was standardized by titration with the standardized sodium hydroxide to the phenolphthalein end point.

\section{Colloidal Ferric Hydroxide}

A suspension of colloidal, hydrated ferric hydroxide was prepared by the procedure outlined by Brescia, et al. A 2.5M solution of ferric chloride (Mallinckrodt Analytical Reagent) was prepared by dissolving the solid in nanopure water. Two milliliters of the concentrated ferric chloride solution was added to $150 \mathrm{~mL}$ of nanopure water and boiled to produce the colloidal suspension. The colloidal suspension was dialyzed until there was no longer residual chloride in the rinse solution when tested with a silver nitrate 
solution. The concentration of the resulting colloidal suspension was approximately $3.3 * 10^{-2} \mathrm{M}$ in total iron.

\section{Goethite $[\alpha-\mathrm{FeO}(\mathrm{OH})]$}

A sample of natural goethite (Ward's Natural Science) was ground to less than 100 mesh and suspended in nanopure water to remove the fines and possible impurities. After 30 seconds, the water was decanted off and the process repeated four more times. The remaining sediments were dried in a $110^{\circ} \mathrm{C}$ oven for 2 hours.

An X-ray powder diffraction pattern was taken of the sample using a Philips XRG-3000 x-ray diffractometer to confirm the identity of the mineral sample. The diffraction pattern confirmed the identity of the sample as goethite, and also indicated the possible presence of trace amounts of amakinite $\left[\left(\mathrm{Fe}_{0.73} \mathrm{Mg}_{0.22} \mathrm{Mn}_{0.05}\right)(\mathrm{OH})_{2}\right]$.

\section{pH 4-12 Buffers}

A series of buffers covering the $\mathrm{pH}$ range 4 through 12 in $0.5 \mathrm{pH}$ increments was prepared. Solutions chosen were acetic acid $(\mathrm{pKa}=4.76), \operatorname{PIPES}\left[\right.$ Piperazine-N, $\mathrm{N}^{\prime}-\mathrm{bis}(2-$ ethanesulfonic acid)] (pKa $=6.80)$, TRIS [Tris (hydroxymethyl) aminomethane] (pKa $=8.30)$, and CAPS [3(cyclohexylamino)propanesulfonic acid] $(\mathrm{pKa}=10.4)$. These buffers were chosen to minimize complexation with iron. The acetic acid was obtained from J.T. Baker Chemical Co. and the PIPES, TRIS, and CAPS were obtained from Sigma Chemical 
Co. The 1M solutions of hydrochloric acid and sodium hydroxide were used in conjunction with these compounds to prepare the desired buffer solutions. All buffers were prepared and diluted with nanopure water, and filtered through $0.2 \mu \mathrm{m}$ filters before use to remove bacteria. Table IV lists the detailed preparation of each buffer with the resulting $\mathrm{pH}$ and ionic strength. The $\mathrm{pH}$ values were measured using a Lazar Digital pH meter with a Corning general purpose combination electrode calibrated against $\mathrm{pH}$ $4.01,7.00$ and 10.00 standard buffers.

TABLE IV

PREPARATION OF BUFFERS WITH ACTUAL $\mathrm{pH}$ 's, IONIC STRENGTHS, AND BUFFER SYSTEM

\begin{tabular}{cccccc} 
pH & $\begin{array}{l}\text { Moles } \\
\text { Acid }\end{array}$ & $\begin{array}{l}\text { Moles } \\
\text { Base }\end{array}$ & $\begin{array}{c}\text { Actual } \\
\text { pH }\end{array}$ & $\begin{array}{c}\text { Ionic } \\
\text { Strength }\end{array}$ & Buffer \\
\hline 4 & $6.622 \mathrm{E}-2$ & $1.074 \mathrm{E}-2$ & 3.93 & $1.074 \mathrm{E}-1$ & HOAC \\
4.5 & $2.777 \mathrm{E}-2$ & $1.074 \mathrm{E}-2$ & 4.45 & $1.074 \mathrm{E}-1$ & HOAC \\
5 & $1.563 \mathrm{E}-2$ & $1.074 \mathrm{E}-2$ & 4.99 & $1.074 \mathrm{E}-1$ & HOAC \\
5.5 & $1.178 \mathrm{E}-2$ & $1.074 \mathrm{E}-2$ & 5.49 & $1.074 \mathrm{E}-1$ & HOAC \\
6 & $8.428 \mathrm{E}-3$ & $1.003 \mathrm{E}-2$ & 6.13 & $8.428 \mathrm{E}-2$ & PIPES \\
6.5 & $6.527 \mathrm{E}-3$ & $1.002 \mathrm{E}-2$ & 6.55 & $6.527 \mathrm{E}-2$ & PIPES \\
7 & $3.813 \mathrm{E}-3$ & $9.977 \mathrm{E}-3$ & 7.12 & $3.813 \mathrm{E}-2$ & PIPES \\
7.5 & $1.670 \mathrm{E}-3$ & $1.002 \mathrm{E}-2$ & 7.68 & $1.670 \mathrm{E}-2$ & PIPES \\
8 & $6.549 \mathrm{E}-3$ & $1.001 \mathrm{E}-2$ & 8.15 & $6.549 \mathrm{E}-2$ & TRIS \\
8.5 & $3.736 \mathrm{E}-3$ & $1.000 \mathrm{E}-2$ & 8.56 & $3.736 \mathrm{E}-2$ & TRIS \\
9 & $1.648 \mathrm{E}-3$ & $1.003 \mathrm{E}-2$ & 8.94 & $1.648 \mathrm{E}-2$ & TRIS \\
9.5 & $8.958 \mathrm{E}-3$ & $9.999 \mathrm{E}-4$ & 9.68 & $9.999 \mathrm{E}-3$ & CAPS \\
10 & $3.512 \mathrm{E}-3$ & $9.999 \mathrm{E}-4$ & 10.21 & $9.999 \mathrm{E}-3$ & CAPS \\
10.5 & $1.795 \mathrm{E}-3$ & $9.999 \mathrm{E}-4$ & 10.76 & $9.999 \mathrm{E}-3$ & CAPS \\
11 & $1.247 \mathrm{E}-3$ & $9.999 \mathrm{E}-4$ & 11.22 & $9.999 \mathrm{E}-3$ & CAPS \\
11.5 & $1.089 \mathrm{E}-3$ & $9.999 \mathrm{E}-4$ & 11.40 & $9.999 \mathrm{E}-3$ & CAPS \\
12 & 0 & $9.999 \mathrm{E}-4$ & 12.12 & $1.022 \mathrm{E}-2$ & NaOH
\end{tabular}

Supporting Electrolyte

The supporting electrolyte used in the polarographic 
analysis was acetate buffer ( $\mathrm{pH} 5.1)$, prepared by isothermal distillation from acetic acid (Allied Chemical) and ammonium hydroxide. The ionic strength of the supporting electrolyte solution was 0.03 .

\section{Solochrome Violet RS}

The Solochrome Violet RS was purchased from ICN Biomedicals and used without further purification. A stock solution, $1.5 * 10^{-4} \mathrm{M}$, was prepared fresh daily.

\section{Standard Iron Solution}

A stock iron solution was prepared by dissolving a weighed quantity of Hach Iron Powder $(99.9+8)$ in perchloric acid (Merck \& Co.) with gentle heating and oxidizing to ferric iron with hydrogen peroxide. To produce the standard ferric solution used for the experiment, the stock solution was diluted and sodium citrate (Mallinckrodt Analytical Reagent) added to prevent the precipitation of iron. The concentrations of the iron and citrate in the standard solution were $4.000 * 10^{-6} \mathrm{M}$ and $3.002 * 10^{-5} \mathrm{M}$, respectively.

\section{Solubility Measurements}

Three series of solubility measurements were made; one with colloidal iron(III) hydroxide, one with goethite, and one in which aqueous iron(III) perchlorate was added and the precipitate formed in situ. For each equilibration, $30.0 \mathrm{~mL}$ of buffer was placed in a 50mL polypropylene centrifuge tube 
("Oakridge" type, Nalgene) under sterile conditions. To one series of buffers was added $1 \mathrm{~mL}$ of $0.04000 \mathrm{M}$ aqueous ferric perchlorate; to the next was added $1 \mathrm{~mL}$ of colloidal ferric hydroxide suspension which contained a total of 0.032 moles of $\mathrm{Fe}^{3+}$ per liter; and to the third was added $0.1 \mathrm{~g}$ of solid goethite. At the $\mathrm{pH}$ with the highest theoretical iron solubility, the total ferric iron placed into the tubes exceeded the total expected concentration of dissolved iron by approximately one hundred.

The solutions were equilibrated by constant agitation on a vertical rotating wheel at 14 RPM in a constant temperature compartment $\left(25^{\circ} \mathrm{C}\right)$ for 3 months. This reaction time is more than adequate to reach equilibrium [Biederman and Schindler, 1957].

\section{Iron Analysis}

Willard and Dean [1950] reported that the single reductive voltammetric wave of Solochrome violet RS (Figure 3) was split into two waves in the presence of aluminum ions. The height of the second wave, which was $0.2 \mathrm{~V}$ more negative that the first, was proportional to the aluminum concertration. The reduction of the aluminum complex of SVRS occurs at a more negative potential than the free dye, because the complex is more stable and requires a greater voltage to bring about reduction. Later studies showed that SVRS can be used to determine several metal ions, including iron(III). 
The mechanism for the reduction of the SVRS compound at the mercury electrode has been determined with reasonable certainty [Florence and Belew, 1969]. The reduction involves a potential determining 2-electron step giving an unstable hydrazo intermediate, which rapidly disproportionates. Disproportionation yields two amines and the original SVRS azo compound.

$$
\begin{aligned}
& -\mathrm{N}=\mathrm{N}-+2 \mathrm{H}^{+}+2 \mathrm{e}^{-} \Leftrightarrow-\mathrm{NH}-\mathrm{NH}- \\
& 2-\mathrm{NH}-\mathrm{NH}-\Rightarrow-\mathrm{N}=\mathrm{N}-+2-\mathrm{NH}_{2}
\end{aligned}
$$

The reduction of SVRS has a working range of at least $\mathrm{pH} 3$ through 11, however, the reduction potential becomes more negative with increasing $\mathrm{pH}$ (i.e. $\mathrm{E}_{\frac{3}{2}}=-0.278 \mathrm{~V}$ at $\mathrm{pH} 4.30$ and $E_{k}=-0.573 \mathrm{~V}$ at $\mathrm{pH} 9.20$ ) [Florence and Belew, 1969]. While the mechanism for the reduction of the SVRS is well known, the mechanism for the reduction of the iron/SVRS complex is still under investigation.

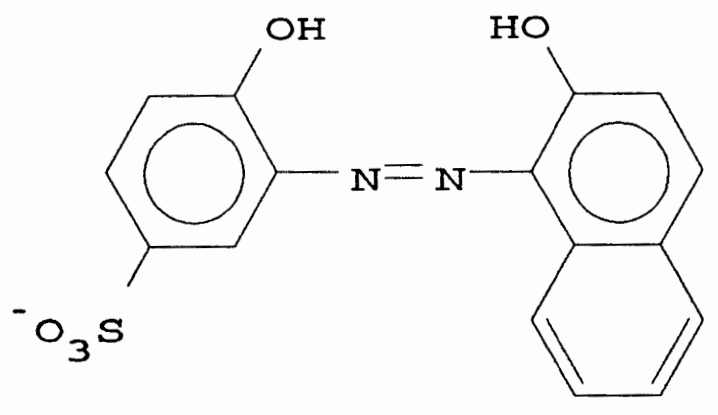

Figure 3. Structure of Solochrome violet RS (5-sulfo2-hydroxybenzene-azo-2-naphthol, C.A.\#[2092-55-9]). 
This method of adsorptive CSV in the presence of SVRS involves the formation of a surface-active complex of Fe(III)/SVRS, and its interfacial accumulation onto the hanging mercury drop electrode. The complex is then quantified by reductive voltammetric stripping of the adsorbed complex. The current produced by reduction of the surface concentration of the ion complex is proportional to the solution concentration. The complexation and interfacial accumulation of the Fe(III)/SVRS system can be described by the following equations [Wang, et al., 1987]:

$$
\begin{aligned}
& \mathrm{Fe}^{3+}+\text { SVRS } \Leftrightarrow[\text { FeSVRS }]^{3+} \\
& {[\text { FeSVRS }]^{3+} \Leftrightarrow[\text { FeSVRS }]_{\text {adsorbed }}^{3+}}
\end{aligned}
$$

Analytical Procedure. The analytical procedure used to determine iron(III) concentrations is similar to that used by Wang and Mahmoud [1987].

Ten milliliters of the supporting electrolyte solution ( $\mathrm{pH} 5.1$ acetate buffer) containing $1.5 * 10^{-6} \mathrm{M}$ of SVRS was plastic tip pipetted into the electrolytic cell, and deaerated by bubbling with nitrogen for 8 minutes. Deaeration was stopped and the nitrogen was passed over the solution surface while the preconcentration potential (usually $-0.10 \mathrm{~V}$ ) was applied to a fresh mercury drop with the solution being stirred. Following the 30 second preconcentration period, stirring was stopped. After a 15 second equilibration time, a voltammogram was recorded using differential pulse polarographic stripping, by applying a 
negative going linear scan from $-0.10 \mathrm{~V}$ to $-1.10 \mathrm{~V}$ at a scan rate of $10 \mathrm{mV} / \mathrm{sec}$. After the background voltammogram was obtained, aliquots of the standard iron(III) solution were added and voltammograms obtained. All analyses employed the standard addition method and all voltammograms were recorded at room temperature.

\section{POSSIBLE SOURCES OF IRON CONTAMINATION}

with decreasing concentration of iron(III) to be determined, contamination can prevail to such an extent that the analytical results can be incorrect by orders of magnitude. In the determination of extremely low concentrations of iron(III) the various sources of contamination were investigated.

\section{Water}

Because of the low concentrations of iron to be determined, it was important to obtain water which had a lower concentration of iron than that to be determined. The best water that could be obtained contained approximately $10^{-8} \mathrm{M}$ iron. Both Nanopure water and Q-water gave this result. Even at this low level, adsorptive CSV gives a large iron peak.

While water in this iron concentration range may not give extremely accurate results, accurate results in ultralow concentration determinations of heavy metals are extremely difficult to obtain [Boutron, 1990]. 
Solochrome Violet RS

Iithough any iron impurities in the SVRS would have been subtracted out with the background, it was still considered as a possible source of iron contamination. The amount of iron that would have to be in the SVRS to create the concentrations seen was calculated to be approximately $18 \mathrm{w} / \mathrm{w}$ of the SVRS used. This large quantity of impurity seemed unreasonable, therefore the SVRS was not purified further. Wang and Mahmoud [1987] also found that commercial SVRS did not require further recrystalization.

\section{Citrate}

Voltammograms were recorded with successive standard additions of $3.4 * 10^{-5} \mathrm{M}(63.88 \mathrm{ng} / \mathrm{L})$ sodium citrate to determine if the citrate contained iron impurities or would interfere with the electrochemical method. The data obtained are listed in Table $\mathrm{V}$.

\section{TABLE V}

CONCENTRATION OF CITRATE ( $\mathrm{ng} / \mathrm{mL}$ ) ADDED AND THE RESULTING PEAK CURRENT INCREASES

\begin{tabular}{cc} 
Citrate Added $(\mathrm{ng} / \mathrm{mL})$ & Current $(\mathrm{nA})$ \\
\hline 0 & 153.125 \\
6.12 & 181.250 \\
12.24 & 196.875 \\
18.36 & 212.500 \\
24.48 & 225.000
\end{tabular}

The data indicate a linear increase with a slope of $2.86 \mathrm{nA} /(\mathrm{ng} / \mathrm{mL})$ and a correlation coefficient of 0.99 . The slope indicates the presence of iron in the citrate 
solution. The iron in the citrate solution can be attributed, in part, to the water used to prepare the solution. The increase in peak current is insignificant as small quantities of citrate are used during the analytical procedure.

\section{Pipet Tips}

Although the pipet tips were acid washed, iron that had not been removed in the acid washing process, can desorb during use. This hypothesis was not tested, as the literature [Mart, 1979; and Gretzinger, et al., 1982] suggests that this is not a problem for the small volumes of dilute samples pipetted.

\section{Syringes And $0.20 \mu \mathrm{m}$ Filters}

Aliquots of the original buffer solutions were analyzed with and without filtering; any change in the calculated concentration between the filtered and non-filtered aliquots could be due to the adsorption or desorption of iron from either the syringes or the filters. Table VI presents the data collected from the buffers analyzed, including the change in concentration due to filtration. A positive value indicates an increase in ixon concentration due to filtration and a negative indicates a decrease. While changes in the iron concentration are apparent, there is not a significant increase or decrease in the total concentration. 


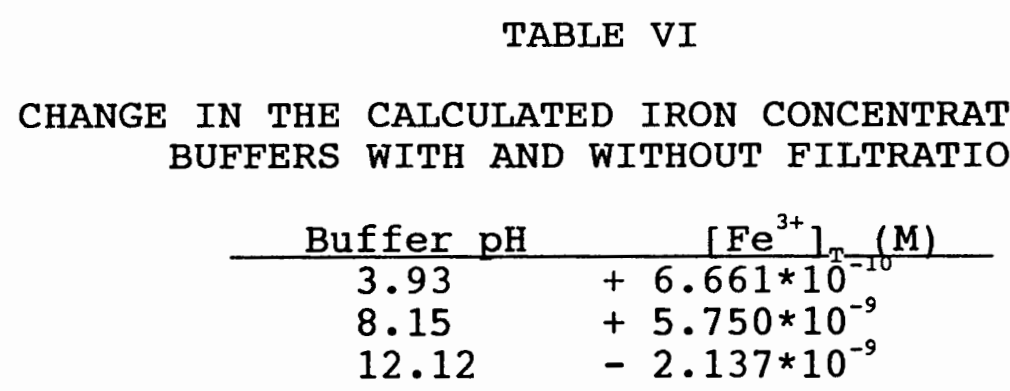

The changes in concentration of iron due to filtration are very sporadic and no conclusion, except the fact that the syringes and filters have a small impact on the concentration, can be drawn.

\section{Colloids}

The $0.2 \mu \mathrm{m}$ filters are probably too coarse to collect all colloidal iron particles. These colloidal particles could then dissolve in the $\mathrm{pH} 5.1$ acetate buffer, increasing the concentration of dissolved iron. Kennedy, et al. [1974] presented a study on the effects of filter pore-size on the analysis of some metal ions, including iron, in water samples. The study found that approximately $10.5-17.5 \mu \mathrm{g} / \mathrm{L}$ $\left(1.9 * 10^{-7}\right.$ to $\left.3.1 * 10^{-7} \mathrm{M}\right)$ colloidal iron can pass through a $0.22 \mu \mathrm{m}$ filter, but are retained on a $0.10 \mu \mathrm{m}$ filter. The study mentioned that very small amounts of particulates can pass through $0.10 \mu \mathrm{m}$ filters.

To determine the effects of the dissolution of colloidal iron hydroxide on the analysis, an aliquot of a colloidal ferric hydroxide suspension was placed into an 
electrolytic cell containing the supporting electrolyte/SVRS solution. Voltammograms were obtained on the solution as a function of time to determine if the dissolution of the colloidal material was affecting the peak current. Figure 4 is a plot of approximate concentration versus time. The resulting plot shows an approximate linear relationship with a slope of $5.62 \mathrm{nA} / \mathrm{min}$ (approximately $\left.3.0 * 10^{-8}(\mathrm{~mol} / \mathrm{L}) / \mathrm{nA}\right)$ and a correlation coefficient of 0.99 . This indicates that there may be a significant increase in peak current due to colloidal particles that pass through the $0.20 \mu \mathrm{m}$ filter. The high $\mathrm{pH}$ equilibration solutions may be more affected by the dissolution of colloids. Lengweiler, et al. [1961b] demonstrated that at lower $\mathrm{pH}$ 's few colloidal particles were found; large size colloidal particles were formed near $\mathrm{pH} 7$ with particle size decreasing through the higher $\mathrm{pH}$ range. The $\mathrm{pH}$ effect on particle size was evident by the lack of particulate matter retained on the $0.2 \mu \mathrm{m}$ filters of the lower $\mathrm{pH}$ range solutions. Large amounts of particulate matter was retained on the filters of the mid-pH range solutions with decreasing amounts retained on the filters of the higher $\mathrm{pH}$ solutions.

The presence of colloids may also affect the peak current by interfering with the equilibrium between aqueous $\mathrm{Fe}^{3+}$ and SVRS in the solution, or by decreasing the concentration of SVRS below the optimum requirement. If active sites on the colloidal surface were to complex with 


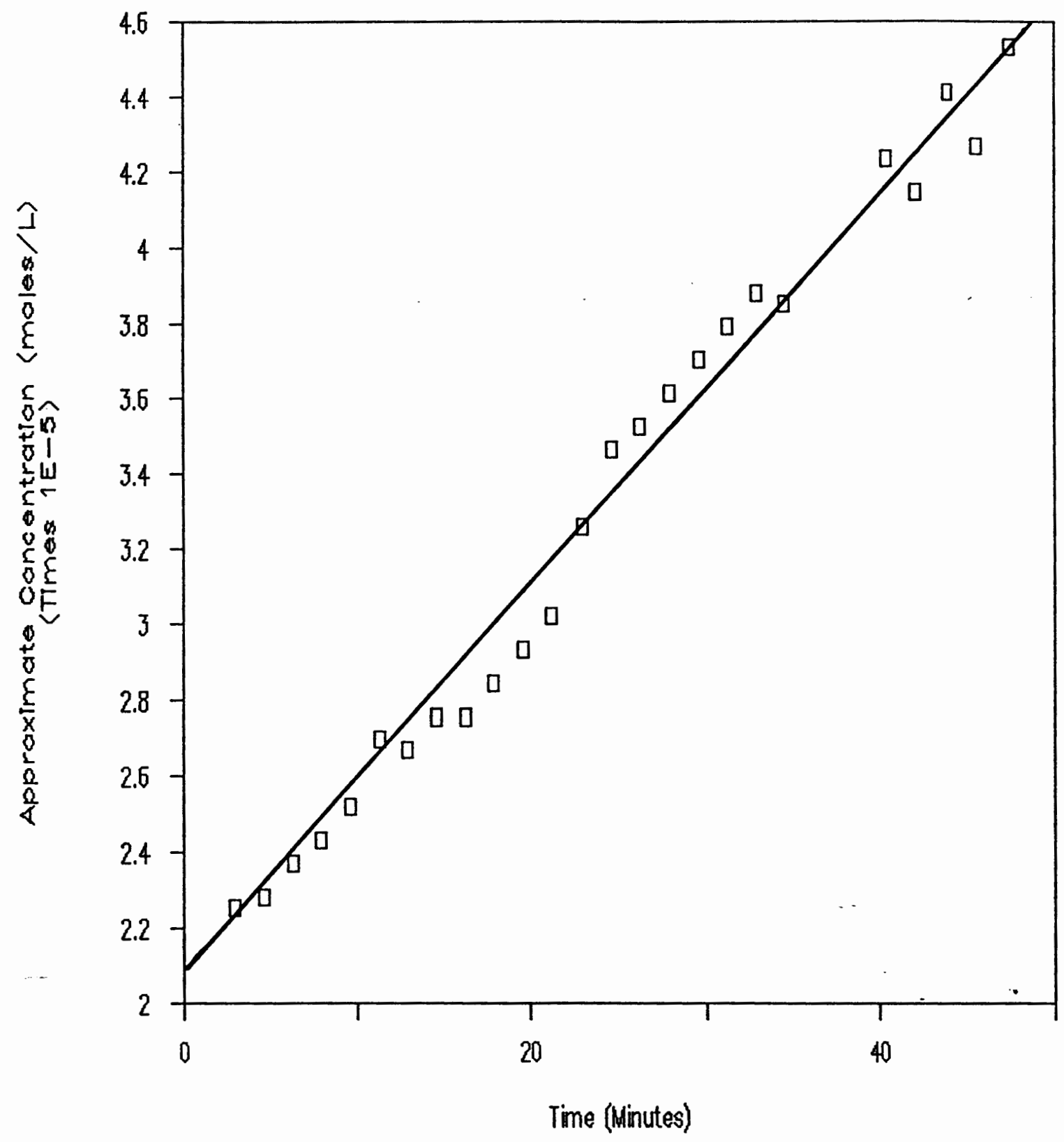

Figure 4. Concentration versus time showing the dissolution of colloidal ferric hydroxide. The slope is $5.62 \mathrm{nA} / \mathrm{min}$ (about $\left.10^{-2.7}(\mu \mathrm{g} / \mathrm{mL}) / \mathrm{nA}\right)$ with a correlation coefficient of 0.99 . 
SVRS in the same manner as the aqueous iron, the colloid/SVRS complex could adsorb on the mercury drop increasing the peak current as the complex is reduced. On the other hand, if several SVRS molecules were to react with each colloid particle, reduction of the adsorbed complex would decrease the peak current.

The possible effects of colloid/SVRS complexation were examined by adding increasing increments of colloidal ferric hydroxide suspension, in excess relative to iron solubility, into two series of vessels containing $12 \mathrm{~mL}$ of the $\mathrm{pH} 5.1$ acetate buffer. One series of vessels was allowed to equilibrate for 2 days, the other for 7 days. When equilibrium is reached, the concentration of dissolved iron should be equal; whereas the amount of colloidal material in the vessels will be increasing with increasing colloidal suspension added. Upon determination of the concentration of iron in the samples, an increase in the concentration can be attributed to the reduction of the colloid/SVRS complex. Figure 5 represents iron concentration determined versus total moles of iron per liter for both the 2 and 7 day equilibrations. The concentrations remained fairly constant with increasing colloidal concentration. This indicates that the peak current is not affected by the presence of colloidal material in the solution.

\section{Metal Ions}

Wang and Mahmoud [1987] tested several metal ions at 


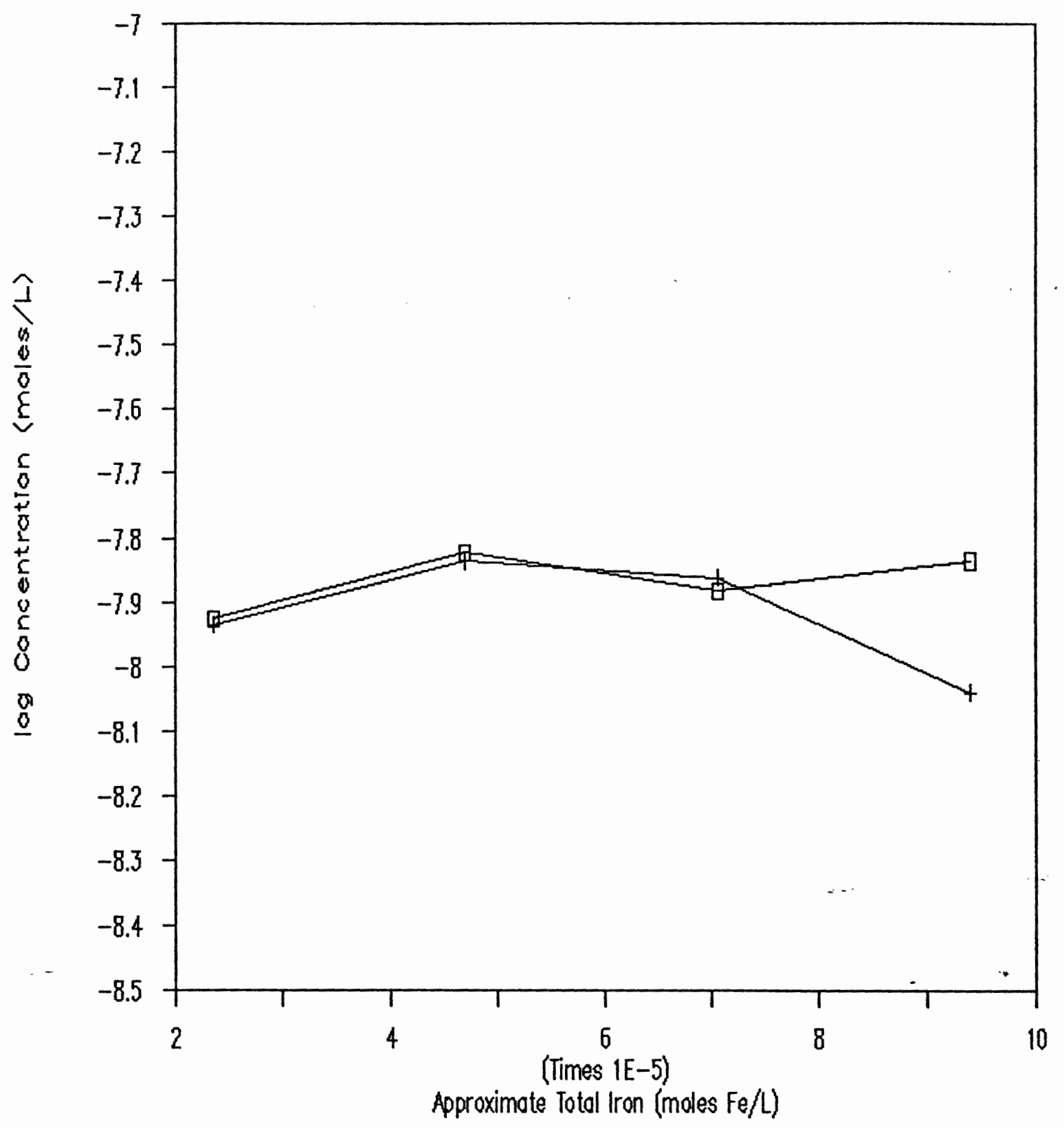

Figure 5. Concentration versus total iron added as colloidal ferric hydroxide. (ㅁ) Two day and $(+)$ Seven day equilibration. 
$50 \mu \mathrm{g} / \mathrm{L}$ and found that they do not interfere with the determination of iron(III). Under the conditions of their experiment, they concluded that $50 \mu \mathrm{g} / \mathrm{L} \mathrm{Al}{ }^{3+}$ created a minor current increase to the iron/SVRS peak. To determine if Al(III) will interfere with the determination of iron concentration, a sample of the supporting electrolyte/SVRS containing iron was spiked with $100 \mu \mathrm{L}$ of $10^{-4} \mathrm{M} \mathrm{Al}\left(\mathrm{NO}_{3}\right)_{3}$ and a voltammogram obtained (Figure 6 ). The addition of Al(III) to the sample resulted in the appearance of an additional peak at $-0.76 \mathrm{~V}$, however, there was no increase in the iron/SVRS peak. From this demonstration it was determined that $A l$ (III) will not interfere with the determination of iron concentrations.

\section{Electrode Frit}

When the $\mathrm{Ag} / \mathrm{AgCl}$ reference electrode is in contact with iron in solution, some of the iron may diffuse into the electrode frit. When a solution of lower iron concentration comes in contact with the frit, the iron can diffuse back out of the frit at a rate which may increase the iron concentration in solution.

A solution containing the normal concentration of iron $\left(1.9 * 10^{-7} \mathrm{M}\right)$ was placed in contact with the electrode for a period of 1 hour. The solution was then removed and the electrodes thoroughly washed with $1 \%$ nitric acid and deionjzed water. A solution of supporting electrolyte/SVRS containing $7.8 * 10^{-8} \mathrm{M}$ iron (to ensure visualization of the 
iron/SVRS peak) was analyzed as a function of time to determine if iron was diffusing out of the electrode frit.

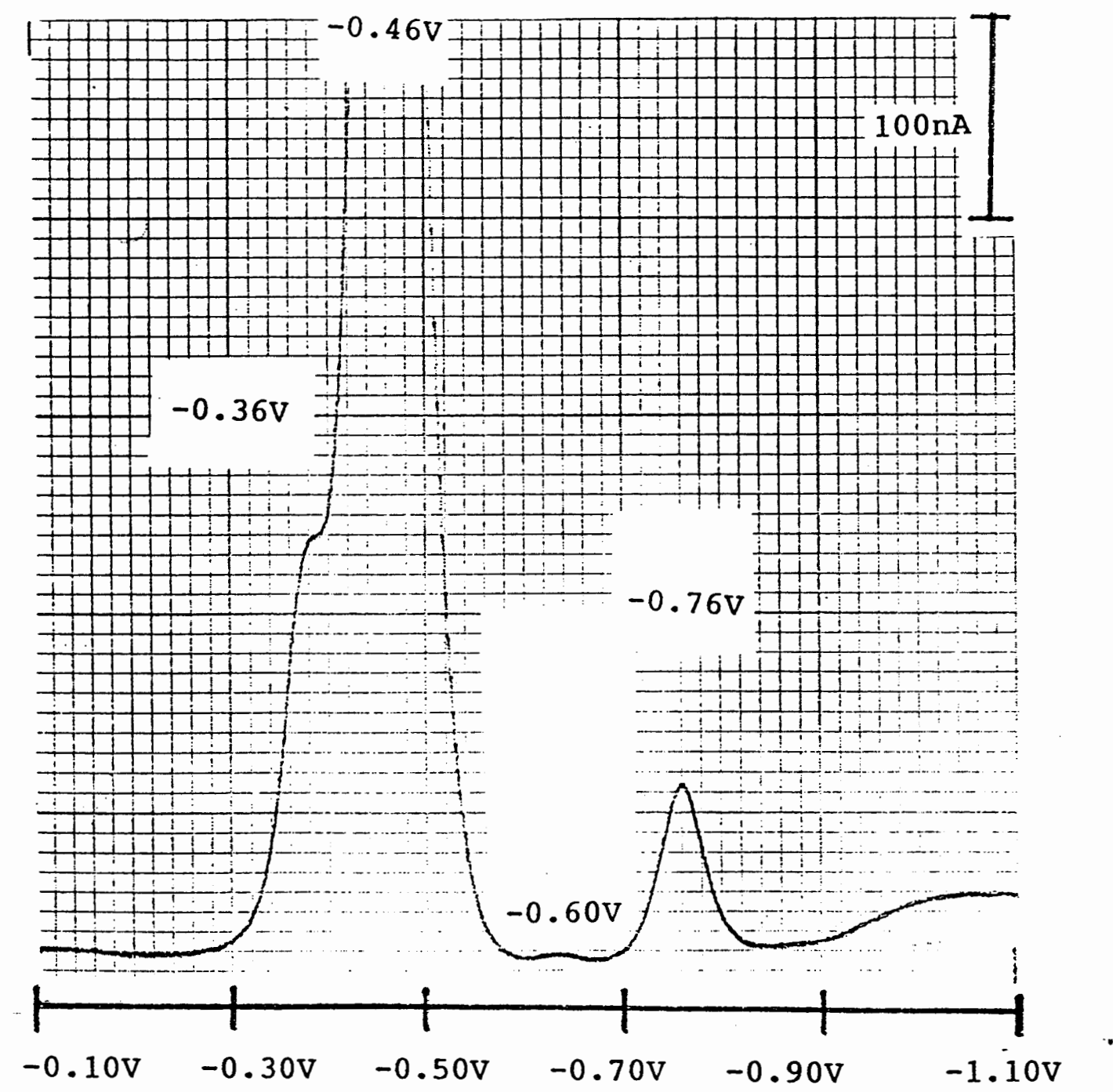

Figure 6. Differential pulse voltammogram of solution containing supporting electrolyte/SVRS and iron, spiked with Al(III). The addition of $\mathrm{Al}$ (III) results in a peak at $-0.76 \mathrm{~V}$ (see current scale in upper right).

Figure 7 shows the resulting graph of the data. The data show a linear increase in current with time. The slope of 


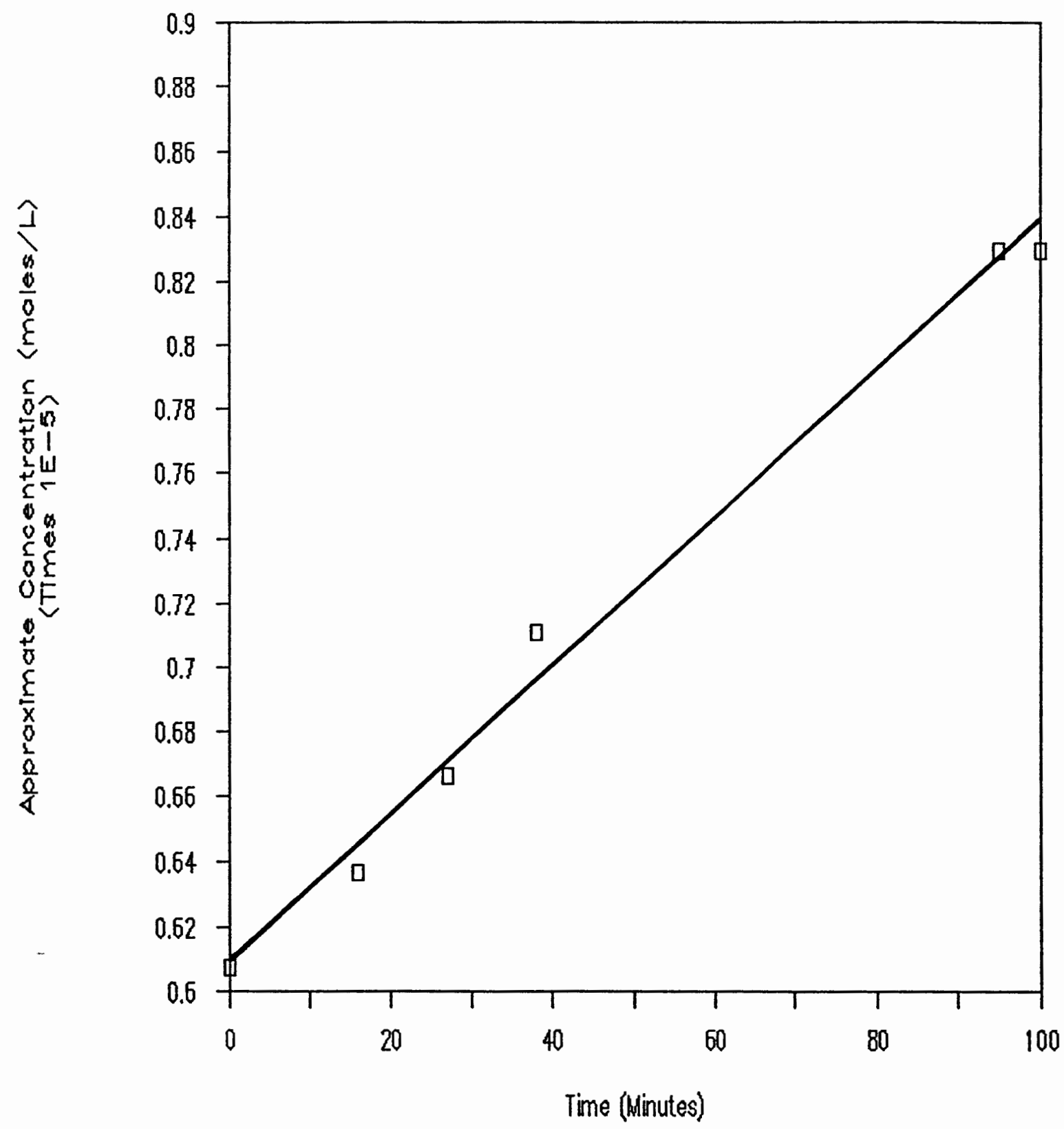

Figure 7. Approximate concentration of iron as a function of time to determine the extent of contamination resulting from iron diffusion out of the electrode frit. 
this line is $0.2414 \mathrm{nA} / \mathrm{min}$ with a correlation coefficient of 1.00. While there is an increase in current with time, the increase would not significantly alter the peak current of iron in solution. If iron can diffuse out of the frit, perhaps some of the $\mathrm{Ag}^{+}$can diffuse out of the frit as well. Wang and Mahmoud [1987] did not consider this in their analysis of the effects of other metal ions on the iron/SVRS peak. A sample solution was spiked with $5 * 10^{-7} \mathrm{M} \mathrm{Ag}^{+}$to determine if it would interfere with the iron/SVRS peak. The addition of the silver to the sample showed no increase in the peak current, indicating that silver was not responsible for an increase in peak current with time.

\section{Purge Gas}

To determine the effects on the peak current due to nitrogen gas, voltammograms were obtained with and without solution stirring and nitrogen purging. When the solution was not purged with nitrogen, nitrogen was still passed over the solution to prevent oxygen from entering the system. The data obtained from the voltammograms was plotted, and the resulting slopes obtained indicate the increases in current with time. Table VII lists the various conditions and the resulting increases in current. The data suggest that the nitrogen gas has a significant effect on the peak current, even when the solution is not purged it appears that iron is entering the system possibly a result of the nitrogen gas passing over the solution. To ensure these 
results were indeed an effect of the nitrogen, two separate test solutions were analyzed by recording the peak current increase as a function of varied purge times. The results found the current increases to be 1.977 and $1.948 \mathrm{nA} / \mathrm{min}$, indicating the nitrogen gas may be a possible source of iron contanination.

\section{TABLE VII}

\section{INCREASES IN CURRENT WITH TIME AT VARIOUS CONDITIONS INVOLVING SOLUTION STIRRING \\ AND NITROGEN PURGING}

\begin{tabular}{cc} 
Conditions & Current Increase \\
\hline Stir/Purge & $0.8984 \mathrm{nA} / \mathrm{min}$ \\
Stir/ -- & 0.4911 \\
$--/$ Purge & 0.9961 \\
$--/--$ & 0.3906
\end{tabular}

To rule out the possible effects of the stir bar causing the release of iron from the cell surface by abrasive action, voltammograms were obtained without the preserce of a stir bar in the solution. When the solution was analyzed without nitrogen purging or passing over the surface, there was no increase in the iron/SVRS peak current. This ruled out any effects of iron increase due to abrasive effects from the stir bar.

It was speculated that the increase in peak current due to purge gas could be a result of dust particles from the activated carbon or zeolite columns in the gas train, which pass through the $0.20 \mu \mathrm{m}$ filter or from gaseous forms of iron in the nitrogen. While the existence of gaseous forms of 
iron(III) are rare, ferric chloride $\left(\mathrm{FeCl}_{3}\right)$ and ferric carbonyl $\left(\mathrm{Fe}(\mathrm{CO})_{5}\right)$ can exist in the gaseous phase. The effects of gaseous forms of iron is pure speculation, and the most probable effect is the existence of dust particles entering the solution. 


\title{
CHAPTER III
}

\author{
RESULTS \\ DIFFERENTIAL PULSE POLAROGRAPHY
}

\section{Instrumental Characteristics}

Prior to the collection of analytical results, voltammograms were obtained to ensure the system was functioning as previously reported. Figure 8 shows voltammograms for SVRS in acetate buffer in the absence (a) and presence $(b, c)$ of iron(III).

When the SVRS-containing solution was stirred for 30 seconds with the electrode held at $-0.1 \mathrm{v}$ prior to the scan, a large cathodic peak associated with the reduction of the adsorbed SVRS is observed at $-0.46 \mathrm{~V}(\mathrm{a})$. A smaller peak is observed at $-0.36 \mathrm{~V}, 0.10 \mathrm{~V}$ more positive than the SVRS reduction peak. Florence and Belew [1969] attribute this peak to a 1-electron reduction process. When the same experiment is conducted in the presence of iron(III) (b), an additional peak associated with the reduction of the adsorbed Fe(III)/SVRS complex is observed at $-0.60 \mathrm{~V}$. The peak height of the iron/sVRS complex increases if the deposition potential is changed to $-0.50 \mathrm{~V}$ (c). The increased peak height can be explained by the reduced competition by the uncomplexed SVRS for sites on the hanging 
mercury drop. To increase analytical response, all voltammograms for the determination of ultratrace levels of iron were obtained using a $-0.50 \mathrm{~V}$ preconcentration potential.

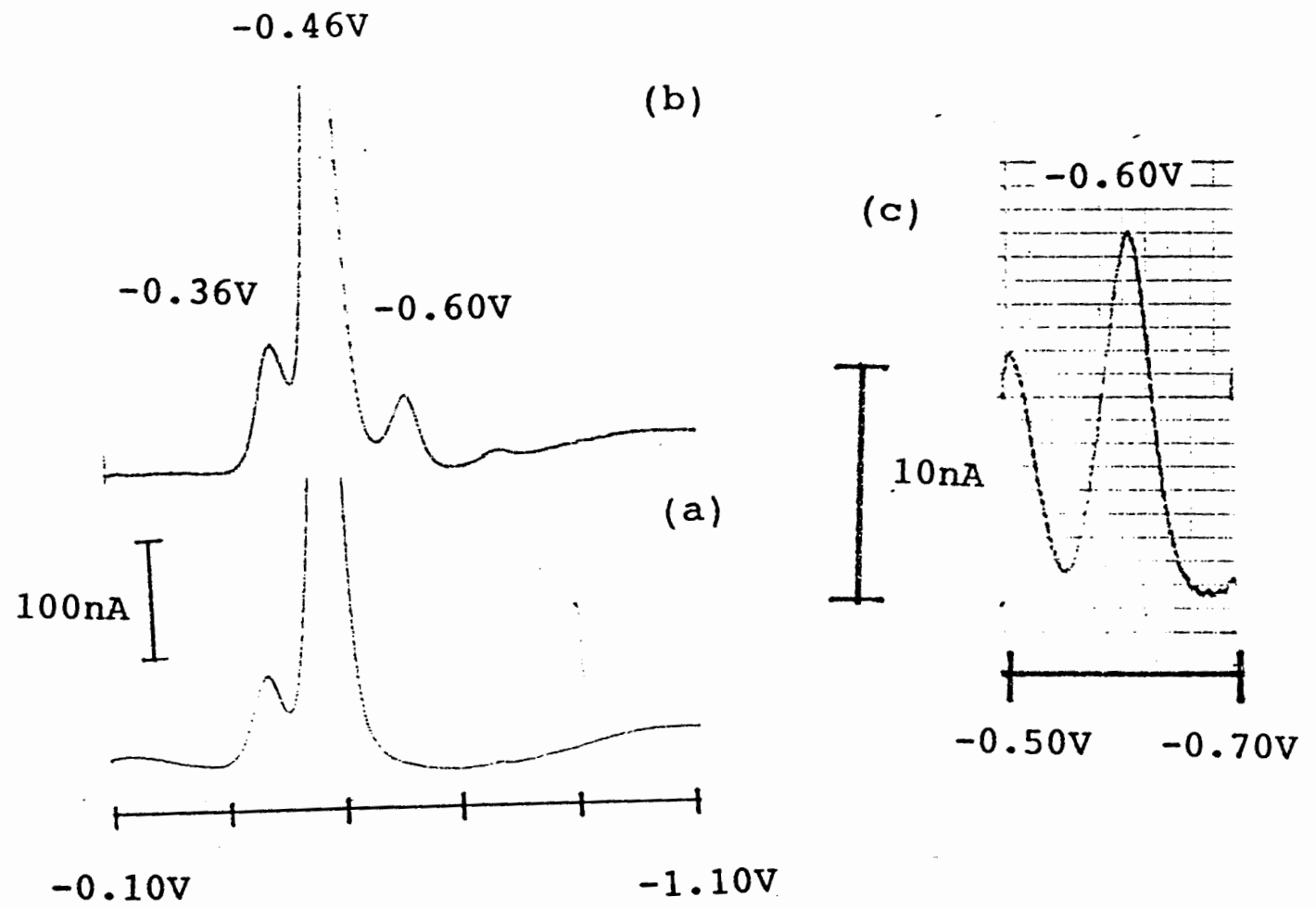

Figure 8. Voltammograms obtained in the differential pulse mode for sVRS containing solutions in the absence (a) and presence $(b, c)$ of added iron.

To ensure that the instrumentation would give a linear response over the concentration range required, voltammograms were recorded with successive standard additions of $2.11 \mu \mathrm{g} / \mathrm{L}\left(3.773 * 10^{-8} \mathrm{M}\right)$ iron. Figure 9 shows linear scan voltammograms in the differential pulse mode for 
iron solutions of increasing concentration, 2.11-8.44 $\mathrm{g} / \mathrm{L}$. Figure 10 depicts the peak current versus concentration of iron added. The resulting plot gives a straight line with a correlation coefficient of 0.99 .

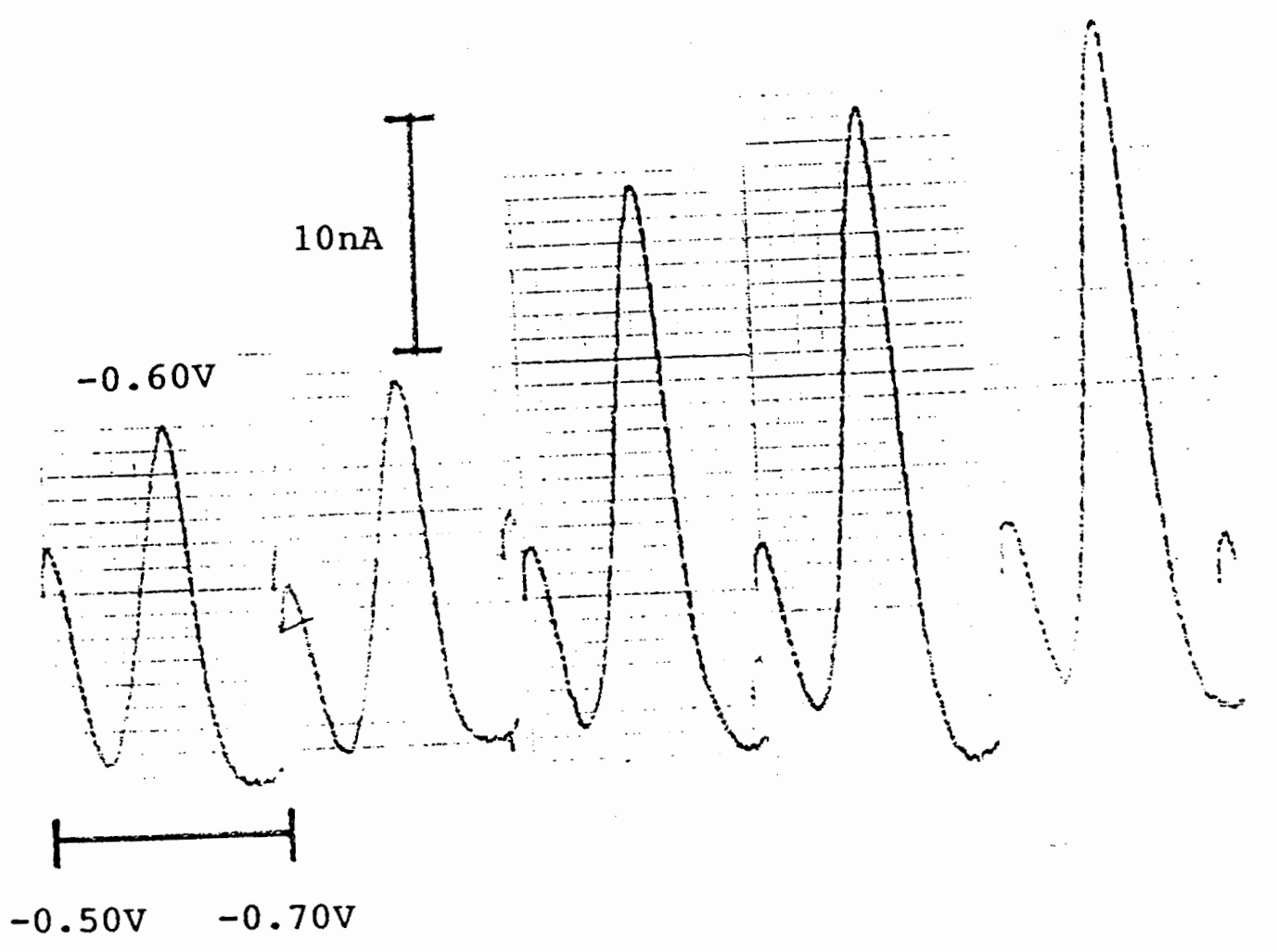

Figure 9. Voltammograms of current versus added iron in the differential pulse mode.

These data indicate a linear relationship between the response (peak current) and the concentration of added iron over the required concentration range.

The parameters used in the study include: the use of a 


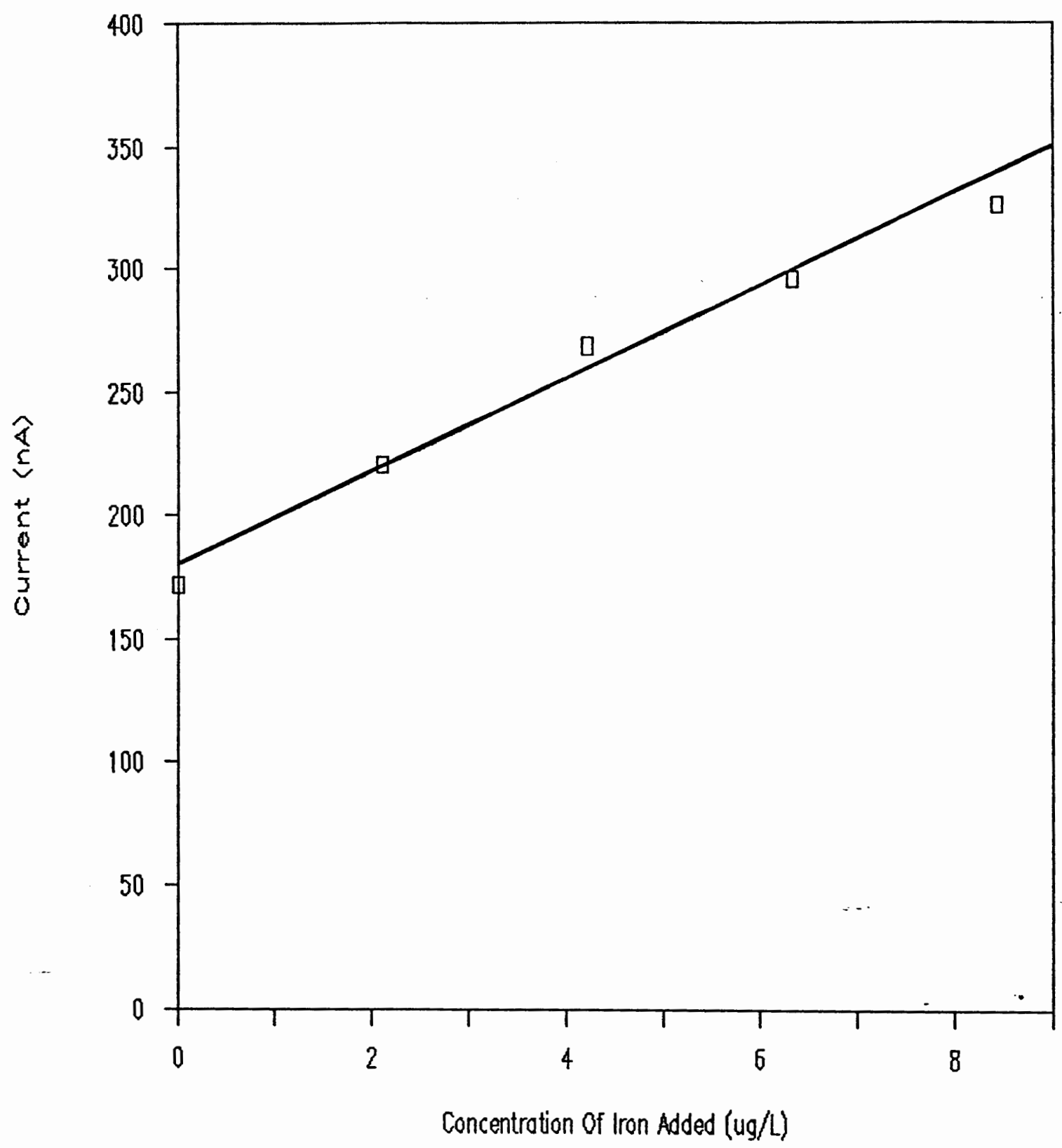

Eigure 10. Analysis of background iron by standard addition for differential pulse polarography. Extrapolation determined background iron to be $2.465 * 10^{-8} \mathrm{M}$, with a correlation coefficient of 0.99 . 
pH 5.1 acetate buffer as the supporting electrolyte; SVRS concentration of $1.5 * 10^{-6} \mathrm{M}$; "medium" mercury drop size; and a 30 second deposition time. These parameters were thoroughly examined by Dean and Bryan [1957]; Florence and Belew [1969]; Wang and Mahmoud [1987]; Wang, et al . [1987]; and van den Berg, et al. [1991].

\section{Analysis of Samples}

Portions of the equilibrated iron/buffer solutions were removed from the plastic centrifuge tubes and filtered through $0.2 \mu \mathrm{m}$ syringe filters (Rainin Instrument Co.) to remove any colloidal material. An aliquot of the filtered sample was placed into the electrolytic cell containing the buffer/SVRS solution. Voltammograms were obtained for the solution and successive standard additions of iron. The resulting data were plotted as current versus concentration of iron added. The concentration of iron in the sample was determined from the $\mathrm{x}$-intercept of the graph.

Due to the ubiquitous nature of iron, it was important to accurately determine the background concentration of iron present in the buffer/SVRS system. Prior to each analysis, background voltammograms were obtained and the background iron concentration calculated. The background concentration was then subtracted from the concentration determined for the equilibrated pH 4-12 buffers. 
Analytical Results. The concentrations of dissolved iron in the buffer solutions equilibrated with a) excess aqueous ferric perchlorate, b) colloidal ferric hydroxide, and c) goethite are tabulated in Table VIII, and the data are plotted in Figures 11, 12, and 13. For comparison, these plots also show the iron solubility as calculated from equilibrium theory.

\section{TABLE VIII}

CONCENTRATION OF TOTAL DISSOLVED IRON(III) CALCULATED FROM AQUEOUS FERRIC PERCHLORATE, COLIOIDAL FERRIC HYDROXIDE, AND GOETHITE AT VARIOUS $\mathrm{pH}$ 'S

\begin{tabular}{lccc} 
& \multicolumn{4}{c}{$\log \left[\mathrm{Fe}^{3+}\right]_{\mathrm{T}}(\operatorname{moles} / \mathrm{L})$} \\
$\mathrm{pH}$ & $\mathrm{Fe}\left(\mathrm{ClO}_{4} \mathrm{~L}_{3}(\mathrm{aq})\right.$ & $\mathrm{Col}$ loidal & Goethite \\
\hline 3.93 & -3.02 & -6.20 & -5.71 \\
4.45 & -4.03 & -5.25 & -5.66 \\
4.99 & -5.31 & -5.36 & -5.88 \\
5.49 & -5.36 & -6.37 & -6.28 \\
6.13 & -5.85 & -6.46 & -6.55 \\
6.55 & -6.64 & $\mathrm{~N} / \mathrm{A}$ & -6.34 \\
7.12 & -6.13 & -6.14 & -6.61 \\
7.68 & -6.26 & -5.87 & -5.58 \\
8.15 & -6.21 & -6.97 & -6.46 \\
8.56 & -5.91 & -6.84 & -6.10 \\
8.94 & -5.59 & -5.97 & -6.28 \\
9.68 & -5.80 & -6.42 & -6.64 \\
10.21 & -8.17 & -6.26 & $\mathrm{~N} / \mathrm{A}$ \\
10.76 & -5.80 & -6.02 & -6.70 \\
11.22 & -6.67 & -5.38 & -5.52 \\
11.40 & -6.25 & -5.73 & $\mathrm{~N} / \mathrm{A}$ \\
12.12 & -5.92 & -5.60 & -6.16
\end{tabular}




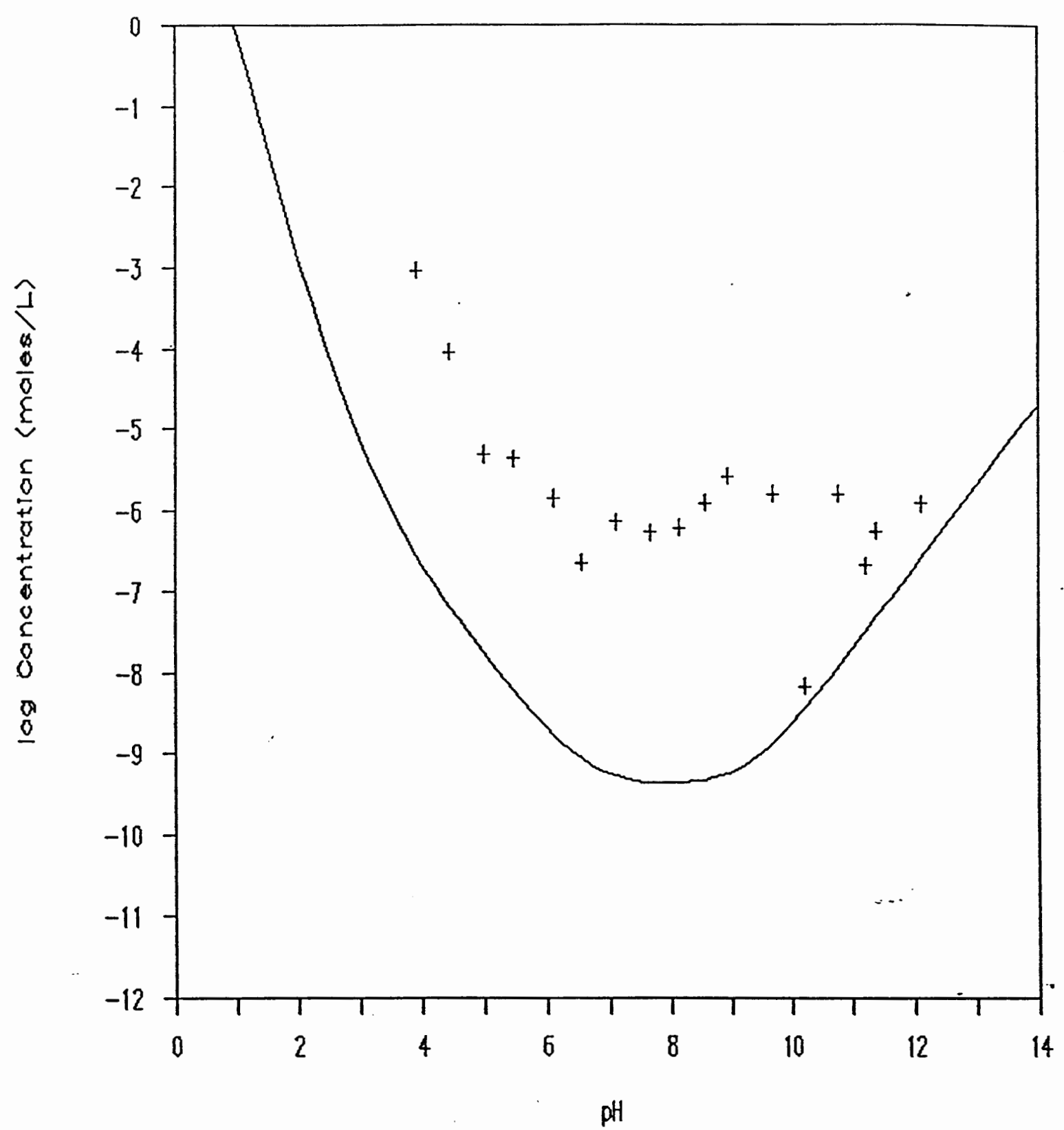

Figure 11. Comparison of calculated solubility $(-)$ with experimental concentrations $(+)$ of iron in solutions equilibrated with ferric perchlorate. $\left(\log K_{8 p}=-39.1, \log K_{11}=-2.19, \log K_{12}=-5.67\right.$, $\log K_{13}=-12.3$, and $\left.\log K_{14}=-21.6\right)$ 


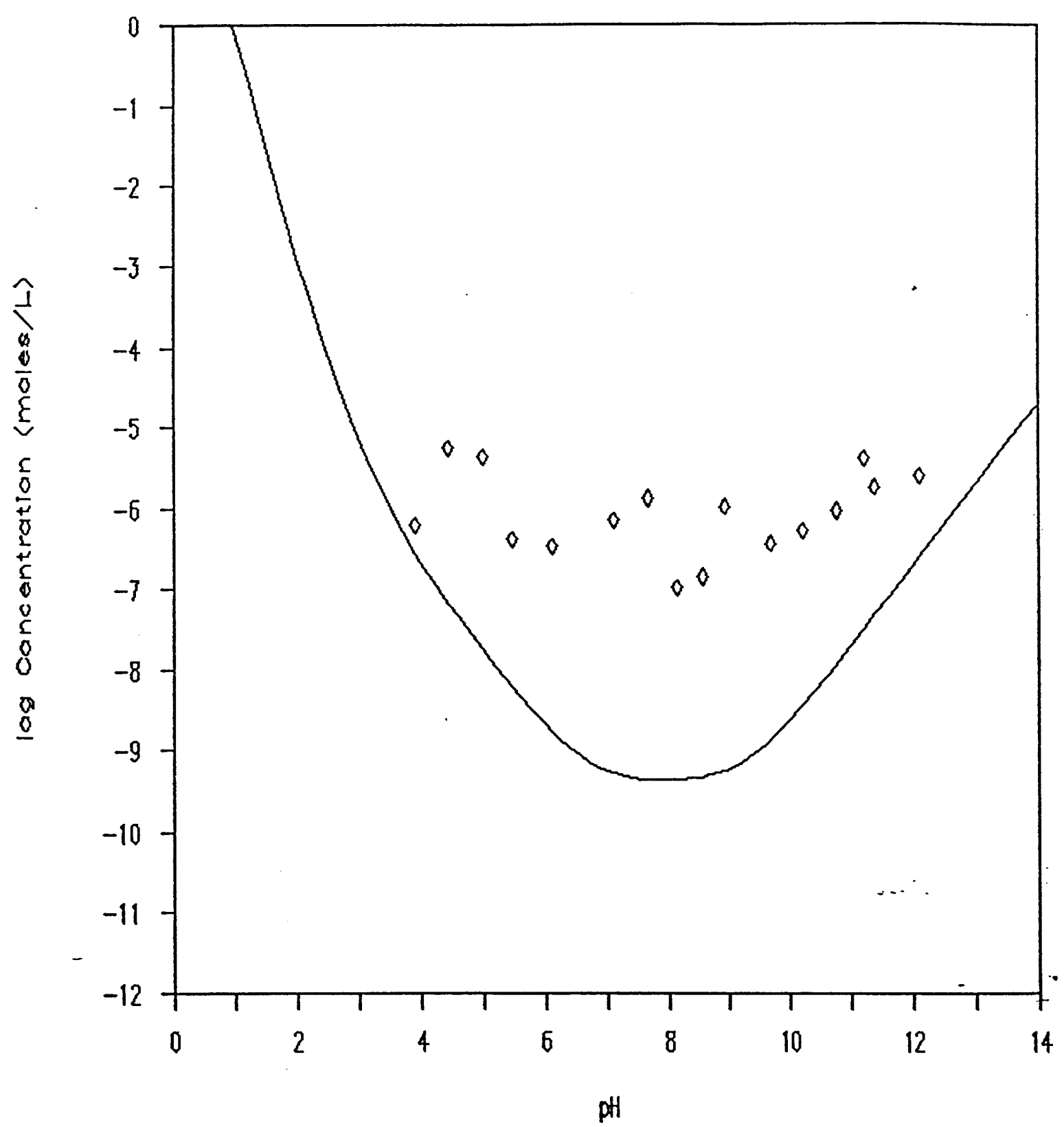

Figure 12. Comparison of calculated solubility $(-)$ with experimental concentrations $(\Delta)$ of iron in solutions equilibrated with colloidal ferric hydroxide. $\left(\log \mathrm{K}_{\mathrm{sp}}=-39.1, \log \mathrm{K}_{11}=-2.19, \log \right.$ $K_{12}=-5.67, \log K_{13}=-12.3$, and $\log K_{14}=-21.6$ ) 


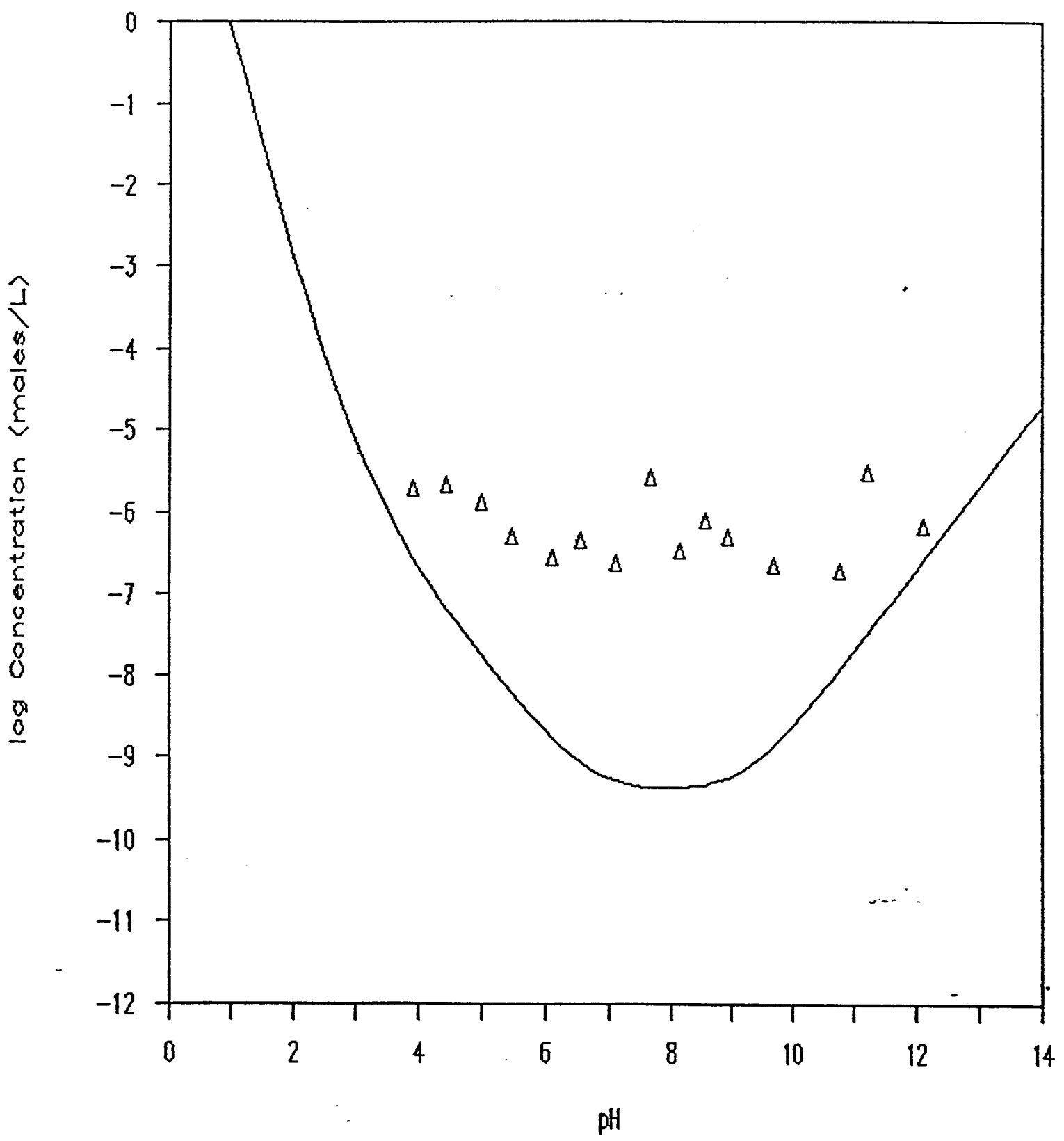

Figure 13. Comparison of calculated solubility $(-)$ with experimental concentrations $(\Delta)$ of iron in solutions equilibrated with goethite. $\left(\log \mathrm{K}_{\mathrm{ep}}=-39.1, \log \mathrm{K}_{11}=-2.19, \log \mathrm{K}_{12}=-5.67\right.$, $\log K_{13}=-12.3$, and $\log K_{14}=-21.6$ ) 
FAST SCAN D.C. POLAROGRAPHY

Wang and Mahmoud [1987] stated that the sensitivity of the procedure can be increased by using fast scan d.c. polarographic adsorptive CSV.

In an effort to improve the determination of iron concentrations in the $\mathrm{pH}$ 6-10 range several methodological procedures were altered to reduce the possibility of iron contamination. To prevent any adsorptive/desorptive losses of iron to glass surfaces, glassware was strictly avoided; except for the electrolytic cell, which was silanized with siliconizing fluid (EG\&G PARC) to pacify the surface. Also, all solutions, including the $\mathrm{pH} 5.1$ buffer and SVRS solutions, were prepared using Q-water in acid washed plastic containers.

\section{Instrumental Characteristics}

When a SVRS containing solution was analyzed, it was noticed that the cathodic peak associated with the reduction of the adsorbed SVRS was observed at $-0.52 \mathrm{~V}$. The same experiment carried out in the presence of iron produced a peak at $-0.81 \mathrm{~V}$, corresponding to the reduction of the iron/SVRS complex (Figure 14).

The shift to more negative potentials could not be explained, however, spiking the solution with iron or SVRS resulted in increases in their respective peaks. As stated earlier, changing the initial potential increases the peak 
current as a result of reduced competition for sites on the mercury drop. The initial potential for the polarographic analysis was begun at $-0.48 \mathrm{~V}$ and terminated at $-1.10 \mathrm{~V}$ with a scan rate of $100 \mathrm{mv} / \mathrm{sec}$. Analysis of the optimal deposition time proved 45 seconds gave the optimal response.

With the new parameters, voltammograms were obtained to determine the background levels of iron in the water.

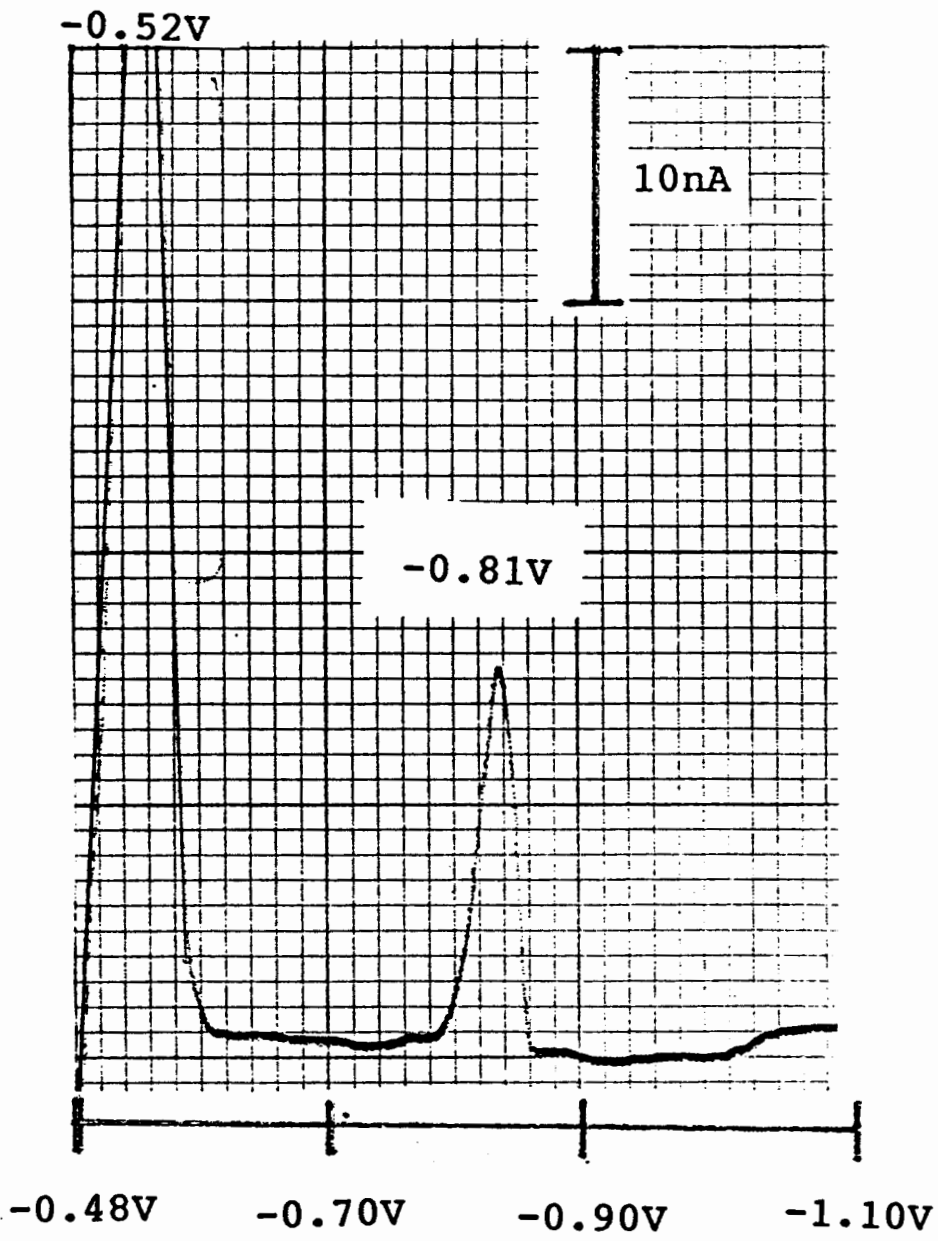

Figure 14. Voltammogram of fast scan $(100 \mathrm{mV} / \mathrm{sec})$ d.c. polarography. 
Figure 15 is a graphical representation of the peak current versus concentration of added iron. The data points indicate a linear response with a correlation coefficient of 0.98. Extrapolation of this line to the $\mathrm{x}$-intercept results in a background iron concentration of $5.916 * 10^{-8} \mathrm{M}$.

Determinations of background iron in Q-water by this method were repeated several times, all resulting in similar concentrations of iron. The concentration of background iron had not improved by this method; therefore, determination of iron concentrations in the $\mathrm{pH}$ 6-10 range was not affected.

Summary. Attempts to lower the background levels of iron were not successful as concentrations below about $10^{-8} \mathrm{M}$ iron could not be attained. This is approximately the level shown by Wang and Mahmoud [1987] and van den Berg, et al. [1991]. Also, it is approximately the same level determined by Barnum ${ }^{3}$ in purified water using a kinetic analysis in which iron(III) catalyzed the oxidation of $\mathrm{N}, \mathrm{N}-$ Dimethyl-pphenylenediamine by hydrogen peroxide [Hirayama and Unohara, 1988].

The signal/noise ratio in both the adsorptive CSV and fast scan differential pulse experiments for the iron peak is still quite high, even at $10^{-8} \mathrm{M}$ iron.

\footnotetext{
${ }^{3}$ Personal communication.
} 


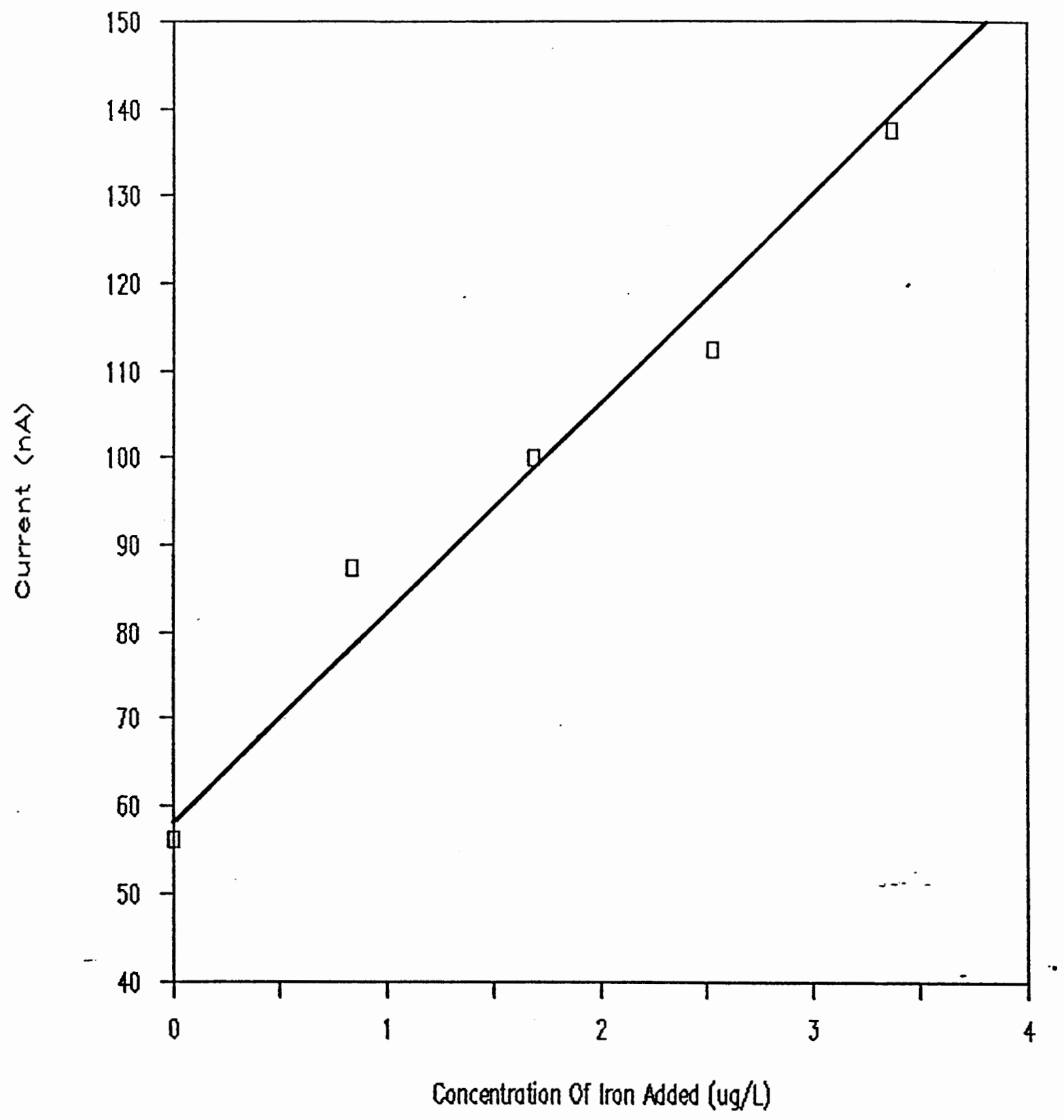

Figure 15. Analysis of background iron by standard addition for fast scan d.c. polarography. Extrapolation determined background iron to be $5.916 * 10^{-8} \mathrm{M}$, with a correlation coefficient of 0.98 . 
CHAPTER IV

DISCUSSION

CONCLUSIONS

Fox [1988] discussed the existence of a nonstoichiometric $\mathrm{Fe}(\mathrm{OH})_{2.35}(\mathrm{X})_{0.65}$. Fox determined the solubility of colloidal ferric hydroxide by dialysis followed by atomic absorption. The results were combined with literature values and plotted as $p a_{\mathrm{Fe}(\text { III) }}$ versus $\mathrm{pH}$, where a represents activity. The plot resulted in a straight line $(r=0.998)$ with the least squares equation:

$$
-\log a_{\mathrm{Pe}(\mathrm{III})}=2.35 \mathrm{pH}-1.17
$$

Rearrangement using $\mathrm{K}_{\mathrm{w}}=10^{-14}$ yielded:

$$
a_{\mathrm{Pe}(\mathrm{III})} / a_{\mathrm{OH}-}^{2.35}=\mathrm{K}_{\mathrm{sp}}=10^{-31.7}
$$

This equation implies a solid phase with the formula $\mathrm{Fe}(\mathrm{OH})_{2.35} \mathrm{X}_{0.65}$.

Figure 16 shows the calculated solubility of $\mathrm{Fe}(\mathrm{OH})_{2.35} \mathrm{x}_{0.65}$ versus $\mathrm{pH}$ using Fox's solubility product, $\mathrm{K}_{\mathrm{sp}}=$ $\left[\mathrm{Fe}^{3+}\right]\left[\mathrm{OH}^{-}\right]^{2.85}=10^{-31.7}$. The plot predicts iron

concentrations much larger than those expressed in the literature as well as those found in this work. These data are compared in Figure 17. The experimental values from this study are approximately two to four orders of magnitude 


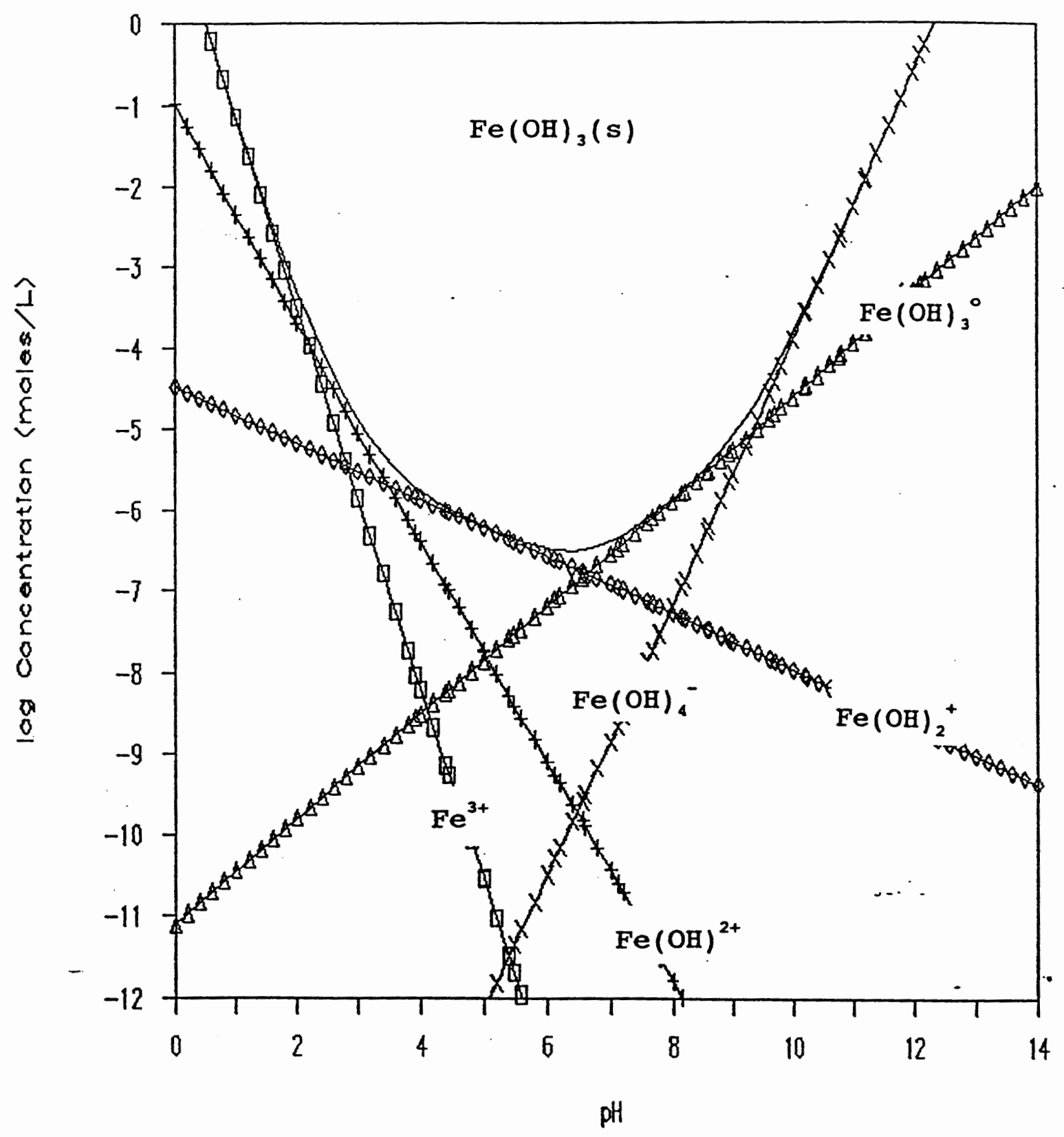

Figure 16. Comparison of the solubility of $\mathrm{Fe}(\mathrm{OH})_{2.35} \mathrm{x}_{0.65}$ calculated $(-1)$ using the solubility product proposed by Fox [1988]. The calculated solubility predicts $\mathrm{Fe}(\mathrm{OH})_{2.35} \mathrm{x}_{0.65}$ will dissolve in excess base, which is not observed. 


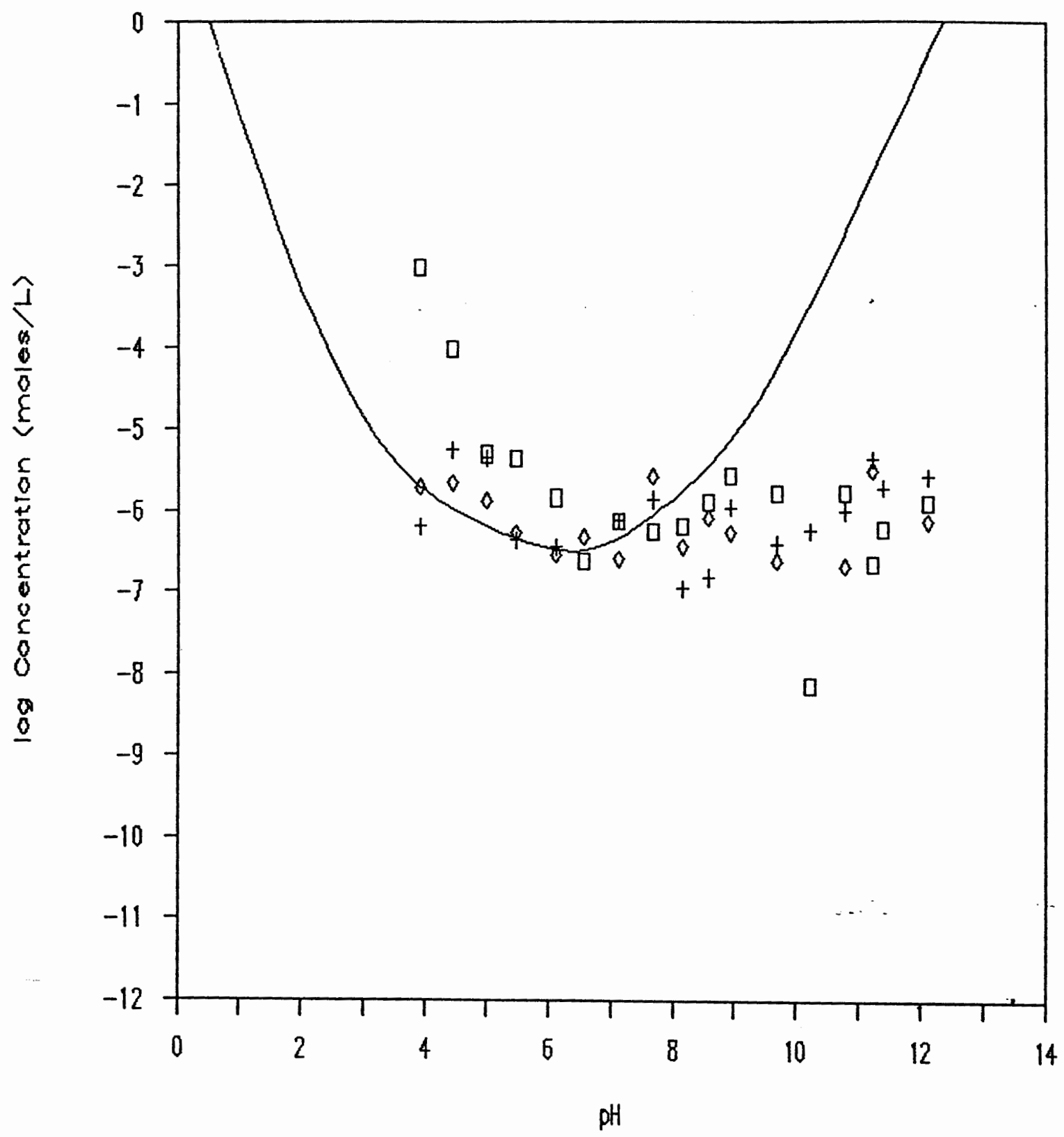

Figure 17. Comparison of the solubility of Fe(OH) $2.35 x_{0.65}$ calculated ( - ) using the solubility product proposed by Fox [1988], with the experimentally measured solubility found in this study (ㅁ) Aqueous ferric perchlorate, $(+)$ Colloidal ferric hydroxide, and ( $)$ Goethite. 
lower than those postulated by Fox in the higher $\mathrm{pH}$ region. For this reason it was determined that the results expressed by Fox would not be pursued further.

Barnum [1983] presented an empirical correlation which enables the prediction of equilibrium constants and standard free energies of formation for metal mononuclear and polynuclear hydroxy complexes. Barnum found the following empirical correlation between the standard free energy of formation for hydroxy complexes and the number of hydroxy groups :

$$
\Delta G_{f}^{\circ}\left\{M(O H)_{y}\right\}=\Delta G_{f}^{\circ}\{M\}+B y+C y^{2}+D / Y
$$

For purposes of interpolating or extrapolating to unknown equilibrium constants this equation was converted into a linear form by combining with the standard free energy of the equation:

$$
\begin{aligned}
& x M^{n+}+y H_{2} O \Leftrightarrow M_{x}(O H)_{y}{ }^{n-y}+y H^{+} \\
& \Delta G^{\circ}=\Delta G_{f}{ }^{\circ}\left\{M(O H)_{y}\right\}-\Delta G_{f}{ }^{\circ}\{M\}-y \Delta G_{f}{ }^{\circ}\left\{H_{2} O\right)
\end{aligned}
$$

Combining these with $\Delta G=-R T l n k$ gives:

$$
\mathrm{U}\left\{\mathrm{M}(\mathrm{OH})_{\mathrm{y}}\right\}=\Delta \mathrm{G}_{\mathrm{f}}{ }^{\circ}\left\{\mathrm{H}_{2} \mathrm{O}\right\}-\mathrm{D} / \mathrm{Y}^{2}-\left(2.303 \mathrm{RT} \log \mathrm{K}_{1 \mathrm{y}}\right) / \mathrm{Y}
$$

where $y$ is the number of hydroxyl groups in the complex and $D=8.37 \mathrm{~kJ} / \mathrm{mole}$ for divalent and trivalent metal ions. When $\mathrm{U}\left\{\mathrm{M}(\mathrm{OH})_{\mathrm{y}}\right\}$ is graphed as a function of $\mathrm{y}$ for metal ions with step-wise hydrolysis, a straight line is produced. These calculations work well for 24 of the metal ions investigated. In the four cases of metal ions that do not fit the empirical correlation, all but scandium(III) can be 
traced to variations in the structure of the hydroxide complex. Barnum's estimated equilibrium constant of $\mathrm{Fe}(\mathrm{OH})_{3}^{\circ}$ is $\mathrm{K}_{13}=10^{-11.89}$ which agrees with the value $\left(<10^{-12}\right)$ preserted by Baes and Mesmer [1976].

The suggestion in recent literature that the value of $\mathrm{K}_{13}$ is significantly lower than previously reported does not fit Barnum's empirical correlation. The values for the equilibrium constants of $\mathrm{Fe}(\mathrm{OH})^{2+}, \mathrm{Fe}(\mathrm{OH})_{2}^{+}$, and $\mathrm{Fe}(\mathrm{OH})_{4}^{-}$have been thoroughly investigated in the literature and the values presented do not vary significantly. Figure 18 shows several literature values of the equilibrium constants graphed as $\mathrm{U}\left\{\mathrm{M}(\mathrm{OH})_{\mathrm{y}}\right\}$ versus $\mathrm{y}$. The correlation coefficient for the data is 0.96 , and removal of the literature values for $K_{13}$ produced a correlation coefficient of 1.00 . The disagreement between Barnum's correlation and the more recent literature values of $\mathrm{K}_{13}$ could be the result of possible structural changes in one or more of the iron(III) hydroxy complexes, which would affect the free energies of formation. Possible changes that could occur are: a shift from high spin to low spin, a change from octahedral to tetrahedral coordination, or the formation of an oxo complex such as $\mathrm{O}=\mathrm{Fe}(\mathrm{OH})\left(\mathrm{H}_{2} \mathrm{O}\right)_{4}$ (octahedral) or $\mathrm{O}=\mathrm{Fe}(\mathrm{OH})\left(\mathrm{H}_{2} \mathrm{O}\right)_{2}$ (tetrahedral).

The idea that $\mathrm{Fe}^{3+}$, a $\mathrm{d}^{5}$ metal ion, could exist in a low spin state is highly unlikely as it has a large exchange stabi]ization energy for its half-filled d subshell [Huheey, 


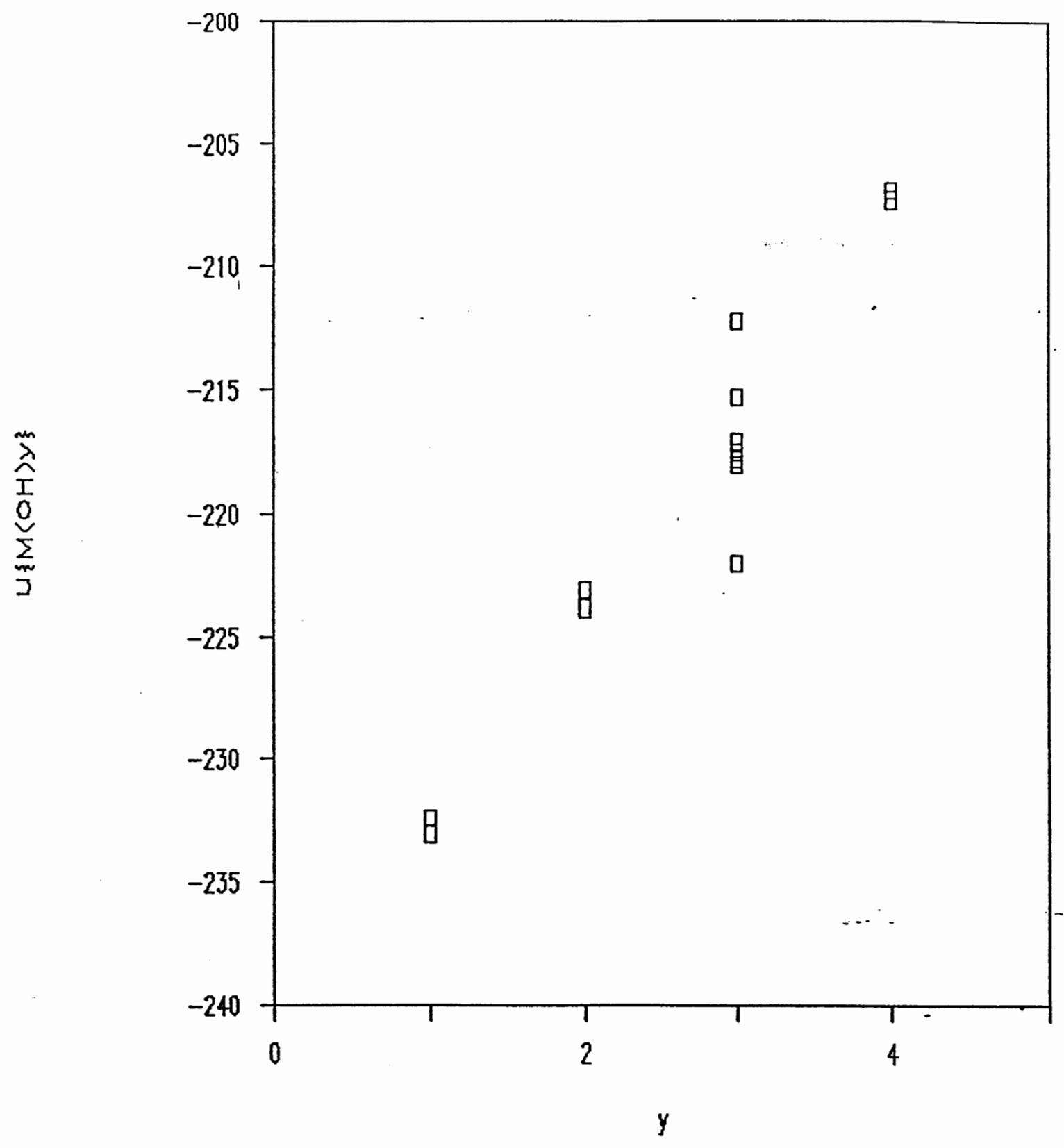

Figure 18. Graphical representation of $\mathrm{U}\left\{\mathrm{M}(\mathrm{OH})_{7}\right\}$ versus $y$ for literature values of the equilibrium constants of the iron(III) hydroxy complexes. 
1983]. Iron(III) is high spin in nearly all its complexes, except those with extremely strong ligands, such as $\left[\mathrm{Fe}(\mathrm{CN})_{6}\right]^{3-},\left[\mathrm{Fe}(\mathrm{bipy})_{3}\right]^{3+}$, and $\left[\mathrm{Fe}(\text { phen })_{3}\right]^{3+}$. While octahedral iron(III) complexes can exhibit spin crossover behavior -- from the high spin configuration, ${ }^{6} A_{1 g}$, to the low spin configuration, ${ }^{2} \mathrm{~T}_{2 \mathrm{~g}}$-- most complexes have a trigonally distorted octahedral configuration with six sulfur atoms [Cotton and Wilkinson, 1988], which the complexes in question do not have.

An ion in an octahedral hole is always at least as stable, and usually more stable, than the same ion in an equivalent tetrahedral field. The increased stability in octahedral fields indicates that iron(III) hydroxy complexes are unlikely to undergo structural changes from an octahedral to a tetrahedral structure.

Iron(III) complexes have the ability to form oxo complexes, although they typically form polymeric complexes such as the $\mu$-oxo dimer:

$2\left[\mathrm{Fe}(\mathrm{OH})\left(\mathrm{H}_{2} \mathrm{O}\right)_{5}\right]^{2+} \Leftrightarrow\left[\left(\mathrm{H}_{2} \mathrm{O}\right)_{5} \mathrm{FeOFe}\left(\mathrm{H}_{2} \mathrm{O}\right)_{5}\right]^{4+}+\mathrm{H}_{2} \mathrm{O}$

Although several possible structural changes can occur, none of them appear to be reasonable explanations for the disagreement between recent literature values of $K_{13}$ and Barnum's empirical correlation. 
FUTURE WORK

Future work in this area should begin with identifying the source of iron in the water supply and reducing background levels to enable more precise measurements of "ultratrace" concentrations of iron(III).

While the method in this study has a detection limit of $7 * 10^{-10} \mathrm{M}$, perhaps another method with a similar, or lower, detection limit could be employed. Another possible method is the kinetic method presented by Hirayama and Unohara [1988]. Regardless of the method, colloidal ferric hydroxide should be strictly avoided. Methods such as the use of smaller sized filters or dialysis would be useful to obtain the desired results. 


\section{CHAPTER V}

\section{REFERENCES}

\section{LITERATURE CITED}

Baes, C. F. and Mesmer, R. E. "The Hydrolysis of Cations"; Wiley-Interscience: New York, 1976.

Barnum, D. W. Inorg. Chem. 1983, 22, 2297-2305.

Biedermann, G. and Schindler, P. Acta Chem. Scand. 1957, $11,731-740$.

Boutron, C. F. Fresenius J. Anal. Chem. 1990, 337, 482-491.

Brescia, F.; Arents, J.; Meislich, H.; and Turk, A.

"Fundamentals of Chemistry: Laboratory Studies";

Academic Press: New York, 1966.

Byrne, R. H. and Kester, D. R. Mar. Chem. 1976, 4, 255-274.

Cotton, F. A. and Wilkinson, G. "Advanced Inorganic Chemistry, Fifth Edition"; Wiley-Interscience: New York, 1988 .

Dean, J. A. and Bryan, H. A. Anal. Chim. Acta 1957, 16, 8793.

Florence, T. M. and Belew, W. L. J. Electroanal. Chem. $1969,21,157-167$.

Fox, I. E. Geochim. Cosmochim. Acta 1988, 52, 771-777.

Gayer, K. H. and Woontner, L. J. Physical Chem. 1956, 60, 1569-1571.

Gretzinger, K.; Kotz, L.; Tschopel, P.; and Tolg, G. Talanta 1982, 29, 1011-1018.

Hirayama, K. and Urohara, N. Anal. Chem. 1988, 60, 25732577 . 
Huheey, J. E. "Inorganic Chemistry, Third Edition"; Harper \& Row, Publishers: New York, 1983.

Kabata-Pendias, A. and Pendias, H. "Trace Elements in Soils and Plants"; CRC Press: Boca Raton, FL, 1984.

Kennedy, V. C.; Zellweger, G. W.; and Jones, B. F. Water Resour. Res. 1974, 10, 785-790.

Kolthoff, I. M.; Sandell, E. B.; Meechan, E. J.; and Bruckenstein, S. "Quantitative Chemical Analysis, Forth Edition"; Macmillian Publishing Company: New York, 1969.

Kuma, K.; Suzuki, Y.; and Matsunaga, K. Wat. Res. 1993, 27, 651-657.

Kuma, K.; Nakabayashi, S.; Suzuki, Y.; and Matsunaga, K. Marine Chemistry 1992, 38, 133-143.

Latimer, G. W. Talanta 1968, 15, 1-14.

Lengweiler, H.; Buser, W.; and Feitknecht, W. Helv. Chim. Acta $1961 \mathrm{~b}, 44,805-811$.

Lindsay, W. L. in Stucki, J. W.; Goodman, B. A.; and Schwertmann, U. (eds.) "Iron in Soils and Clay Minerals"; D. Reidel Publishing Company: Dordrecht, Holland, 1985 .

Mart, L. Fresenius Z. Anal. Chem. 1979, 296, 350-357.

Martell, A. E. and Smith, R. M. "Critical Stability

Constants"; Plenum Press: New York, 1982.

Schwertmann, U. and Taylor, R. M. Clays and Clay Minerals $1972,20,151-158$.

Schwertmann, U. and Taylor, R. M. in Dixon, J. B. and weed, S. B. (eds.) "Minerals in Soil Environments"; Soil Science Society of America: Madison, WI, 1977; pp. 145-180.

Sherman, D. M.; Burns, R. G.; and Burns, V. M. J. Geophys. Res. 1982, 87, 10,169-10,180.

Stumm, W. and Lee, G. F. Hydrol. 1960, 22, 295-319.

Stumm, W. and Morgan, J. J. "Aquatic Chemistry, Second Edition"; Wiley-Interscience: New York, 1981. 
van den Berg, C. M. G.; Nimmo, M.; Abollino, O.; and Mentasti, E. Electroanalysis 1991, 3, 477-484.

Wang, J. and Mahmoud, J. S. Fresenius Z. Anal. Chem. 1987, $327,789-793$.

Wang, J.; Tuzhi, P.; and Martinez, T. Anal. Chim. Acta $1987,201,43-50$.

Willard, H. H. and Dean, J. A. Anal. Chem. 1950, 22, 1264 .

Zafiriou, O. C. and True, M. B. Mar. Chem. 1980, 8, 281288 .

\section{SELECTED BIBLIOGRAPHY}

Benitez, M. J.; Company, M.; Averalillo, A.; and Jimenez, J.

S. Anitmicrob. Agents Chemother. 1991, 35, 1517-1519.

Britton, H. T. S. J. Chem. Soc. 1925, 127, 2148-2159.

Dousma, J. and De Bruyn, P. L. J. Colloid Interface Sci. $1.976,56,527-539$.

Dousma, J. and De Bruyn, P. L. J. Colloid Interface Sci. $1977,64,154-170$.

Drever, J. I. "The Geochemistry of Natural Waters"; Prentice-Hall, Inc.: Englewood Cliffs, NJ, 1982.

Evans, U. R. and Pryor, M. J. J. Chem. Soc. 1949, S157$\mathrm{S} 160$.

Faure, G. "Principles And Applications of Inorganic Geochemistry"; Macmillian Publishing: New York, 1991.

Feitknecht, w. Z. Elektrochem. 1959, 63, 34 .

Florence, T. M. Analyst 1986, 111, 489-505.

Fogg, A. G. and Lewis, J. E. Talanta 1978, 25, 461-467.

Good, N. E.; Winget, G. D.; Winter, W.; Connolly, T. N.; Izawa, S; and Singh, R. M. M. Biochemistry 1966, 5, $467-477$.

Harris, D. C. "Quantitative Chemical Analysis, Second Edition"; W. H. Freeman and Company: New York, 1987. 
Holleck, L.; Abd El Kader, J. M.; and Shams El Din, A. M. J. Electroanal. Chem. 1969, 20, 287-296.

Hughes, R. C.; Murau, P. C.; and Gundersen, G. Anal - Chem. $1971,43,691-696$.

Jones, B. F.; Kennedy, V. C.; and Zellweger, G. W. Water Resour. Res. 1974, 10, 791-793.

Kriukc.v, P. A. and Awsejewitsch, G. P. Z. Electrochem. $1933,39,884-891$.

Landa, E. R. and Gast, R. G. Clays and Clay Minerals 1973, $21,121-130$.

Lengweiler, H.; Buser, W.; and Feitknecht, W. Helv. Chim. Acta 1961a, 44, 796-805.

Mil1, A. J. B. Env. Technol. Letters 1980a, 1, 97-108.

Mill, A. J. B. Env. Technol. Letters 1980b, 1, 109-124.

Moody, J. R. and Lindstrom, R. M. Anal. Chem. 1977, 49, 2264-2267.

Morel, F. M. M. "Principles of Aquatic Chemistry"; WileyInterscience: New York, 1983.

Okamoto, S. J. Am. Ceram. Soc. 1968, 51, 594-599.

Pankow, J. F. "Aquatic Chemistry Concepts"; Lewis Publishers, Inc.: Chelsea, MI, 1991.

Ponnamperuma, F. N.; Tianco, E. M.; and LoY, T. Soil Science 1967, 103, 374-382.

Schweitzer, G. K. and Jackson, M. J. Chem. Ed. 1952, 513522 .

Schwertmann, U. and Fischer, W. R. Geoderma 1973, 10, 237247 .

Towe, K. M. and Bradley, W. F. J. Colloid. Interface Sci. $1967,24,384-392$.

van den Berg, C. M. G. and Huang, Z. Q. J. Electroanal. Chem. 1984, 177, 269-280.

Vassos, B. H. and Ewing, G. W. "Electroanalytical Chemistry"; Wiley-Interscience: New York, 1983. 
Wang, J. "Stripping Analysis: Principles, Instrumentation, and Applications"; VCH Publishers: Deerfield Beach, 1985.

Wang, J. and Mahmoud, J. S. J. Electroanal. Chem. 1986, $208,383-394$.

Wells, A. F. "Structural Inorganic Chemistry"; University Press: Oxford, 1950.

Zinder, B.; Furrer, G.; and Stumm, W. Geochim. Cosmochim. Acta $1986,50,1861-1869$. 